\title{
An action research on the use of therapeutic stories as a new method of piano education
}

\section{Ece Demirayak*}

Tan Temel ${ }^{* *}$

* Responsible Author, Yildiz Technical University, Social Sciences Institute, Music and Perfroming Arts MA Program, Istanbul, Turkey, e-Mail: ecedemirayakk@gmail.com, https://orcid.org/0000-0002-3344-0665 ** Yildiz Technical University, Faculty of Art and Design, Department of Music and Performing Arts, Istanbul, Turkey, e-Mail: ttemel@yildiz.edu.tr, https://orcid.org/0000-0001-5164-0292

DOI 10.12975/rastmd.20219112 Submitted July 18, 2021 Accepted August 29, 2021

\section{Abstract}

This research is an action research on the applicability of therapeutic storytelling in piano instruction. There are many studies showing that art instruction that enables the discovery and development of artistic talent, has positive effects on the psychological states of individuals. No research was found where therapeutic storytelling was used as an instructional method in piano education.

In this study, a preliminary study, in which the researcher was the practitioner, was conducted on the design and implementation process of an instructional method based on therapeutic storytelling for piano students. This study was designed in accordance with action research design in qualitative research methods. Due to the ongoing pandemic process, the participants of the study conducted with the hybrid education model are 3 piano students whose ages are ranging between 10-12. Semi-structured interview form, observation form and documents were used as data collection tools. In the application of therapeutic stories, the preparation of the instructional design, the difficulties experienced, the measures taken for effectiveness were determined through interviews and observations.

The research lasted for 3 weeks. One private lesson of one and a half hours was held with one student each week. In each lesson, 1 therapeutic story was read to the students and the student was asked to create a music composition about the story. In the course setup, predetermined questions were asked to the student while the story was being read, after the story was finished, and during the student's composing process. It was aimed to measure the reactions of the students to the stories through the questions, to examine how these reactions were reflected in the composition process and to determine the effect of the designed instructional method on the motivation of the students.

As a result of the research in teaching piano students based on therapeutic storytelling; It was determined that giving music composition time periods suitable for students' individual differences, instructional differentiation in accordance with the level of student readiness, and the choice of story subject for student interest increase the effectiveness of instructional design.

\section{Key Words}

therapeutic storytelling, music education, piano, instructional design, action research

\section{Introduction}

Storytelling is a tool which is often used in child psychotherapy. Painter (1997) stated that: "Storytelling has been used in child psychotherapy in many forms including the following: (1) fairy tales (Bettelheim, 1977; Franzke, 1989; Thiessen, 1985); (2) the mutual storytelling technique (Gardner, 1969, 1970; Scho- 
oley, 1976); (3) bibliotherapy (Early, 1993; Fleshman \& Fryrear, 1981); (4) the creative characters technique (Brooks, 1981, 1985, 1987); and (5) therapeutic storytelling (Cook, 1993, 1994)." (p:1)

Therapeutic stories are unique and directed at the individual's problems, hopes and fears. (Painter, 1997, p: 4) Painter (1997) stated that: "Therapeutic storytelling has been used to target a wide range of problems including: (1) treatment of sexual abuse (Rhue \& Lynn, 1991); (2) improvement of health care management (Lawlis, 1995); (3) introduction to therapy (Brooks, 1985); (4) treatment of divorce issues (Early, 1993; Gardner 1971); and (5) treatment of problems secondary to chronic illness (Robertson \& Barford, 1979)." (p: 5)

Sunderland (2017, p: 11) suggest that therapeutic stories can suggest healthy coping mechanisms in situations such as aggression, insensitization, emotional consensus to avoid pain, exposure to bullying and not talking about it to anyone, giving his life over to something or someone who is causing him too much hurt.

Therapeutic stories can transform the context of a child's problematic state of life. The therapist can help to cognitively restructure a child and his or her parents based on therapeutic stories. The story offers new possibilities to cope with the situation that is struggling and allows a change in the belief that the situation is hopeless and insurmountable. (Cook et al, 2004, p: 243)

When children's painful and difficultto-deal emotions are left unresolved, these emotions can lead to challenging behaviours and neurotic symptoms.
Children have not developed internal resources to process and digest their uncomfortable emotions. They need help with this. (Sunderland, 2017, p: 1, 2) When a child is able to think about and connect with disturbing emotions through a story, internal confusion can be resolved. (Sunderland, 2017, p: 14) Sunderland (2017) talks about therapeutic stories as a powerful emotional support for children, explaining the importance of this as: "In summary, children desperately need emotional education, and until this is formalised in some way on all school curricula, it is to be hoped that the therapeutic story can go some way towards offering such education." (p.16)

Although therapeutic stories are often used in therapies, there are also therapeutic storybooks for teachers or parents to read to children. Helena Schlindwein's "Zoela's StoriesTherapeutic Children's Stories", Caroline Sheppard's "Brave Bart: A Story for Traumatized and Grieving Children" are examples. Hivda Saldız, Kübra Berrak, and Hayal Çavușoğlu>s "Therapeutic Story Series (Terapötik Hikaye Serisi)" are examples in Turkish.

Many studies have been conducted on the use of therapeutic stories in education. For example, Henter and Chifor presented their work with kindergarten students in their articles entitled “Developing Preschool Children's SocioEmotional Abilities through Therapeutic Stories". A program developed by psychologists featuring therapeutic stories was applied to children with the aim of improving children's socioemotional development. After the study, children showed progress in recognizing 
emotions and not expressing their anger through violent behavior.

Xiu Lui's doctoral thesis entitled "Exploring the Value of Culturally Adapted Therapeutic Stories as a Tool for Intervention in Chinese Primary Schools" examined how primary school counsellors use therapeutic stories in their training and their experiences. Teachers observed that therapeutic stories help children reduce anxiety and increase their attention.

Rizzi, Pigeon et al in their article "Designing a creative storytelling workshop to build self-confidence and trust among adolescents" have mentioned their research aiming to improve adolescents' self-confidence and trusts. Adolescents have designed stories that allow them to express themselves. At the end of the research, they found that adolescents gained more confidence and were more open to making new friends.

No research has been found concerning the use of therapeutic stories in music or piano education. In piano education, children also practice composition on the piano. Composing is a process in which children express their true selves through their creativity. Stories can help this process. It may be easier for children to express their difficult feelings.

Embodying children's emotions through art allows unprocessed emotions to be symbolized. This contributes to a fresh perspective on children's emotional experiences. (Crenshaw, 2008, p: 8, 9) At schools, spaces are created where children, after a story is read, can express their reactions to the story. From this point of view, artistic production is a free way for children to connect with themes in the story. (Baumgartner, 1996, p: 143) Baumgartner (1996) relates the importance of artistic production in the expression of stories: "A story may have greater power to affect the listener if the listener has the opportunity to respond to and draw his/her own meanings from the story, with such activities as writing, drawing, and guided discussion." (p.105, 106) When used in conjunction with the composing process, therapeutic stories that are about the individual's internal processes can contribute to making the instrument a tool for self-expression. This can increase the motivation of children.

Mitchell, in the article named "Therapeutic Music Education: An Emerging Model Linking Philosophies and Experiences of Music Education with Music Therapy" investigated the impact of a therapeutic approach to music education on students. In the research, university music educators gave private voice lessons to music students. These lessons were treated with a therapeutic approach, addressing the musical and personal development of students. At the end of the research, all participants stated that musical and personal development were intertwined and attributed their evolving musical skills to the therapeutic approach applied to them. According to Bauer and Balius (1995, p: 28) "The therapeutic and educational activities supported and enhanced each other." In this context, the use of therapeutic stories in piano education and in the process of composing may also contribute to the motivation and development of students in piano lessons. 


\section{The Problem of the Study}

This research explored the use of therapeutic stories as a new method of piano education, and their role in music composition as a motivator. We examined how therapeutic stories arouse emotions in piano students aged 10-12 and how these emotions are transferred to the composing process. It has been investigated whether these stories alter students' interest in creating compositions and piano lessons.

The researchers also sought answers to questions such as: "What is the impact of creating music compositions with therapeutic stories on the motivation of piano students aged 10-12?", “Could the therapeutic stories contribute to creativity in the process of creating music compositions?" and "Is it possible to use the therapeutic stories as a new method of piano education?"

\section{The Model of the Research}

This research was conducted in accordance with the model of qualitative action research. The researcher took part as an executor in the study. The psychological reactions the students give to therapeutic stories and the way they interpret the stories have been examined through the questions and observation. The students were also asked about the effects of therapeutic stories on the compositions they formed. Music compositions were examined and included in this study along with student responses.

\section{The Participants}

The study involved three piano students aged 10-12. These students have taken piano lessons for at least two years.

Table 1. The characteristics of participants

\begin{tabular}{|l|l|l|l|l|}
\hline Participant No & Gender & Age & Grade & $\begin{array}{l}\text { Period of piano } \\
\text { training }\end{array}$ \\
\hline P1 & Male & 11 & 5 & 7 years \\
\hline P2 & Female & 10 & 4 & 2 years \\
\hline P3 & Female & 10 & 4 & 6 years \\
\hline
\end{tabular}

The first participant is a 11 year old boy. He has been studying piano for seven years. For the last year, the piano education process has continued together with the researcher. During this year, he conducted various composition works and with the help of the researcher, wrote these compositions. He has never worked on compositions with therapeutic stories before. During this period, he applied to a music composition competition for children.

The second participant is a 10 year old girl. She began her piano education two years ago with the researcher. During this period, she had experiments with music composition outside of her studies. However, these compositions were not written.

The third participant is a 10 year old girl. She has been studying piano for six years. For the last year, the piano education process has continued together with the researcher. She has never done any musical composition work during the year. 


\section{Data Collection Tools}

In this research, semi-structured interview, observation techniques and written documents collected from students were used as data collection tools for reporting. Observation was made in accordance with participant observation pattern. Documents used to report students' compositions created with therapeutic stories, answers to questions, observations, implementation, and solution processes.

\section{The Procedure}

Three piano students between the ages of 10-12 participated in this research. This student group is composed of students who have taken piano lessons for at least two years. The study was conducted over three weeks between 1 July 2021 and 15 July 2021. Each week, one and a half hour of private lessons were held with each student. During the research, the students were read the three therapeutic stories chosen by the researcher. Each lesson was based on a single story. While reading the story; after reading the story and during the music composition process, the students were asked predetermined questions. When deemed necessary, additional questions were asked such as: "What do you think of the dark place in the story? How do you imagine this place?", "Do you share your fears with anyone?", "How do you feel about the difference between composing with a story's help and composing without using a story?"

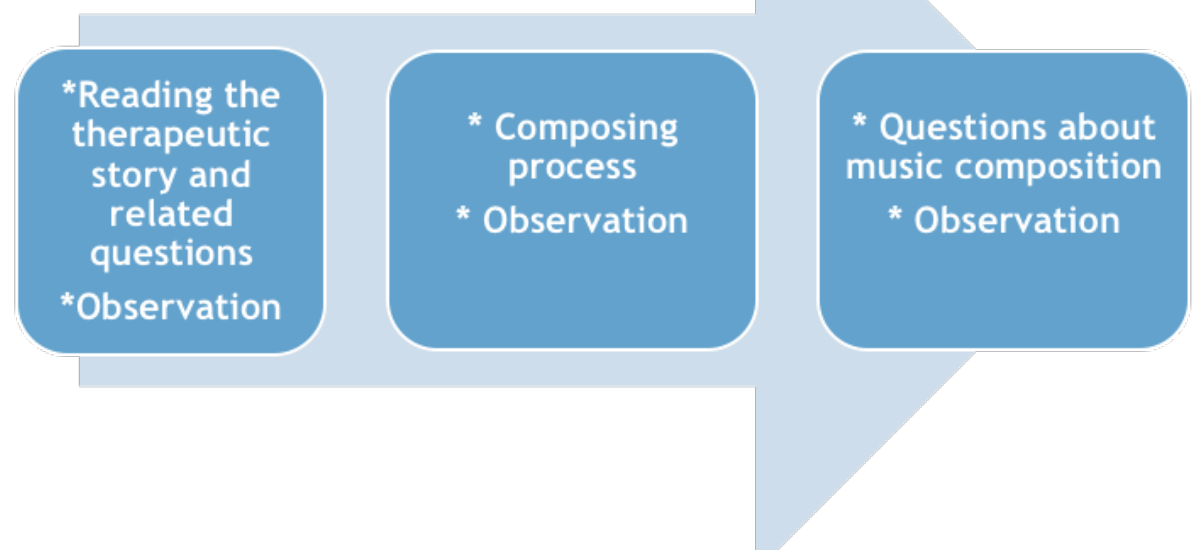

Figure 1. The procedure

Stories were divided into three chapters. For each chapter, children were asked to create a composition based on the story and how they felt about the story. No technical limitations such as time signature, tonality, and symmetry were imposed on children for compositions. Thus, it was thought that the child could express himself/herself more freely. After each composition section was completed, the teacher transmitted the music played by the child through the Musescore ${ }^{1}$ program. Children listened to their composition through the program and edited or approved them by making 1 A music notation program 
additions. After each composition section, the child was asked to describe the similar aspects of the section to the the story. It thus became clear how children used the story to construct the melodies.

\section{The Research Process and Findings}

Students had the opportunity to project their psychological reaction to therapeutic stories into their composition during the research process. In many cases, they chose to use their favorite story parts in their music composition. Although there have been instances of students using similar musical languages for events that appear in stories, this language has generally varied. For example: In the first story, students mentioned the part in which the sun tried to convince the child using high pitches in their compositions. However, the melodic form of the compositions was different for each student.

Based on the stories selected, music compositions produced and the questions asked about the subject, it was determined that the educational practice had a positive effect on students' motivation. It has been established that all students have a positive comment on the process of the educational practice used in the research.

\section{The Stories, Compositions and Related Questions}

Therapeutic stories used in this research have been selected from George W. Burns' book "101 Healing Stories for Kids and Teens-Using Metaphors in Therapy". The researcher did the Turkish translations of the stories. The stories were chosen intended to cope with anger, fear and to distinguish sensory experiences. Stories were chosen as a good tool for expressing difficult emotions such as anger and fear. Similarly, sensory apprehension was also assumed to be important for a child's biopsychosocial development, and music was an effective tool for expressing feelings associated with this awareness. The topic of sensory awareness was also mentioned in the stories.

When designing questions about stories, the intention was to help the child to understand his/her inferences from the story and express his/her feelings. While designing questions about composition and composition sections, the aim was to make sense of the child's connection between story and music.

\section{Story 1. It's In The Way You Do It} (101 Healing Stories for Kids and Teens Using Metaphors in Therapy, p: 54,55$)$

The other day I was talking to a friend I have known for a long time and was surprised to learn something about her that I had never known before. When she was a young child, her mother would sit on her bedside telling her stories, many of which she still remembersand many of them she tells to children today. She said she doesn't know where her mother heard the stories but maybe they were from her mother, or even her grandmother. As we talked she began to tell me some of the stories her mother had told. They had stayed in her memory all that time from her early childhood. One was about the wind, the rain, and the sun.

One day the wind, the rain, and the sun were talking about how to get someone to change what they are doing. Sometimes it can be a big problem if you are doing 
things you don't really want to be doing, or doing things that are not helpful for you or others. Well, this is exactly what the wind, rain, and sun were discussing.

"Let's play a game," said the sun. "See that boy down there wearing a jacket? Let's see who can get him to take it off."

"Let me try first," said the wind eagerly. The wind began to blow past the boy's ear, whispering gently at first, "Take off your jacket. Take off your jacket." When the boy didn't take off his jacket, the wind began to blow a little stronger and call a little louder into his ear, but the stronger it blew, the colder the boy became and the more snugly he wrapped his jacket around him. The wind began to howl louder in his ear.

It was not asking any more but roaring orders at him: "Take off your jacket! Take off your jacket!" The more the boy ignored it, the louder the wind shouted ... and the more the boy ignored it. The wind puffed itself out, blowing and shouting, but the boy snuggled deeper into his jacket, holding it tighter around his body.

"Here, give me a go," called the rain. "Obviously what you are doing isn't working. There is no point screaming at him because the more you do, the more he holds his jacket closer." The rain began to do what it did best. It started to drizzle softly, calling as it dripped past the boy's ears, "Take off your jacket. Take off your jacket." But instead the boy pulled the hood up over his head and zipped up the jacket to seal his body from the rain.

Frustrated, the rain was determined not to give up. It seemed to forget the good advice it had given to the wind. "If he won't listen to me, I'll beat him into taking his jacket off," said the rain, angrily, and with that began to pour heavily. Raindrops pelted against the boy: "Take off your jacket! Take off your jacket!" but still the boy refused to listen. The rain turned into hail and lashed at him, angrily shouting at him to take off his jacket. Instead, the boy tried to cover every part of him that the jacket could hide and looked around, searching for shelter. "It must be my turn," said the sun quietly.

(Question 1: How would you end this story?)

Without speaking a word it started to shine down, drying the boy and his jacket. The sun began to caress the boy in warmth, just gradually raising the temperature of the air without making it too hot. At first the boy slipped back the hood. As the sun continued to gently warm the day, the boy undid the zipper of his jacket. Caringly, the sun raised the temperature another degree or two, all the while caressing the boy in warmth, so that it wasn't long before the boy slipped out of his jacket altogether to enjoy the comfortable warmth of the sunshine.

Question 2: What was your favorite part of this story? Why?

Question 3: What feeling does this story remind you of?

Question 4: Did you like this story? Why do you think you like it? If you don't like it, why don't you? 
Question 5: What do you do when you want someone to do something?

Question 6: Can you explain the similar aspects of the section you composed and the story read?

Question 7: Did the story help you compose?

Question 8: How did it feel to compose this story?

\section{Story 2. Soaring to New Heights: A} Kid Story (101 Healing Stories for Kids and Teens Using Metaphors in Therapy, p: 62, 63)

Once upon a time a little octopus lived in warm, shallow waters close to a sandy beach. Do you know how many legs an octopus has? Yes, eight. And do you know what they are called? That's right. Tentacles. Well, this little octopus loved to wrap its tentacles around things and hang on. It might grab hold of a fish and go for a fun ride. It might hang on to a solid rock that felt strong and secure. One day, as the little octopus was out exploring, it saw a strong, sturdy anchor hanging below a ship. Immediately, the little octopus wrapped its tentacles around the anchor and hung on. Then something scary happened. The anchor began to drop, sinking down into darker, colder waters where the little octopus had never been before. The little octopus didn't like it but didn't know what to do. What do you think you would do if you were the octopus? Would you hang on or let go?

(Question 1: What do you think you would do if you were the octopus? Would you hang on or let go?)
Well, the little octopus hung on until, with a thump, theanchorlandedontheseafloor. Then it hung on tighter. It was frightened and scared of this strange place, and still didn't know what to do. Just then it saw a friendly-looking fish swimming toward it in a gentle, relaxed motion. "Help," called the little octopus. "Can you help me?"

"Yes, I can help you," said the fish. Its eyes seemed kindly and caring. "But, first, you have to help yourself. You need to let go of that anchor, before I can show you a way."

Still the little octopus didn't know what to do. The anchor felt strong. If the octopus let go, it would be alone in the water all by itself. It looked at the fish.

(Question 2: How would you go on with the story from now on?)

The fish nodded encouragingly, and the little octopus began to slowly peel off one tentacle at a time. Having so many legs or arms (and a tentacle is a bit like both) can be nice if you want to hug someone you love, but can make hard work of it if you want to let something go. The last one was the hardest. It needed to hold on just a little longer before building up the courage to set itself free.

The kindly fish waited, encouraging and congratulating. When the little octopus let go of the anchor the fish said gently, "Follow me." It swam back and forth, gradually making its way up toward the bright, warmer waters, guiding the little octopus in a way that it could repeat if ever it got caught out of its depth again. 
The little octopus felt stronger and happier as it swam on. It caught up with the fish and, for a while, they swam side by side. No longer did it need to follow. At times it began to swim ahead, taking the lead and making its own way forward. No longer did it feel out of its depth. In fact, this had been a real adventure. Before long the fish said, "No longer do you need me. You can swim on strongly by yourself now. Enjoy."

The little octopus thanked the fish and swam on upward. The waters continued to grow brighter and warmer. Light rippled off the surface and shone into the sea, highlighting the yellows, reds, and blues of the tiny fish that darted in and out of the colorful coral. The things around the little octopus seemed much the same as before, but now the octopus felt different, stronger, more confident. Then it did something an octopus doesn't usually do. It crawled up onto the beach and stretched out on the sand, basking in the warm sun. It felt nice to relax for a while and do nothing in particular.

The little octopus looked at the limestone cliffs behind the beach. Maybe it had learned to like having adventures. Maybe doing something new didn't feel as scary as it had before. The cliffs looked tempting. The little octopus wondered what it would be like to climb to the top. Carefully, it began its climb toward the cliff top. The going was not always easy, but the little octopus was excited by the challenge. At times it was a struggle but the little octopus pressed on, and wow, what a feeling when it stood on the top. A cool breeze blew in from the ocean.
As naturally as if it had been doing it all its life, the little octopus spread its tentacles out like wings and began to lift on the breeze. Like an eagle it soared into the air, riding the gentle currents, experiencing the joy of flying.

Looking down, the little octopus saw the ocean below. That was where it had come from. Looking up it saw the clear, blue sky above. That was where it was going. Who would have guessed that an ordinary little octopus could have flown to such heights?

Question 3: What was your favorite part of this story? Why?

Question 4: What feeling does this story remind you of?

Question 5: Did you like this story? Why do you think you like it? If you don't like it, why don't you?

Question 6: What do you usually do when you face conditions you're afraid of?

Question 7: Can you explain the similar aspects of the section you composed and the story read?

Question 8: Did the story help you compose?

Question 9: How did it feel to compose this story?

Story 3. Heightening Pleasure: A Teen Story (101 Healing Stories for Kids and Teens Using Metaphors in Therapy, p: 123, 124, 125)

Have you ever been backpacking or camping in the woods? Shelley 
never had. She was a city girl. Her dad would never take his car off a paved road, and her mom would never stay anywhere except in a luxury hotel. Then her class teacher, Ms. McKay, announced they were going on a hiking trip: four days trekking through the woods, three nights camped out in tents. How could she get out of it?

Well, the fact was she couldn't, and so she found herself tramping along with a pack on her back that she was sure even a Sumo wrestler would struggle with. It was a burden she didn't want to bear but she also knew it carried things essential for her survival, so she found herself needing it and hating it at the same time. Was she ever glad to dump it when they finally got to their campsite!

Ms. McKay called the girls together. "When you have set up your tents"-great, how do you do that? wondered Shelley-"I want you to explore the woods near camp. Don't wander too far away." No worries about that, thought Shelley. "I want you to look closely at what you see. Let yourselves discover the colors, the shapes, the shades, the tones, and the movements. Let us make this a silent exercise. While you walk and look, no talking for the first ten minutes." You have to be joking, Shelley mouthed to the friend standing beside her. She didn't know if she had been silent, ever, for ten minutes in her life, apart from sleeping.

She looked up at the trees. Hey, the leaves weren't all green. Each one was a different shade of green-light green, dark green, yellowy-green, they were different sizes and shapes, and moved differently in the breeze. The tree trunks weren't brown. They were gray and brown, and black and green. Some had smooth bark over which you could run your hand, while others were too lumpy or splintery. One tall tree had a hollow trunk just big enough for a teenage girl to hide in. Checking it out to be sure it was free of spiders and snakes, she slipped inside. At least she could hide here till the ten minutes were up, then jump out and startle a passing friend. As she sat there, she watched a shiny beetle making its way up the inside of the trunk; she was fascinated as its delicate legs climbed over mountainous ridges and deep valleys-at least for a beetle-on a journey to where? she wondered. When she heard other kids chattering again she felt reluctant to leave. There was something peaceful about her tree-trunk hideaway and she didn't want to leave her beetle. For a while, she stayed on.

After supper (along with carrying a backpack, she could live without the camp food, Shelley thought) Ms. McKay asked everyone to quietly sit around the campfire, close their eyes if they wished, and listen to the sounds of the forest. The crackle of the fire sounded friendly and warming. The breeze rustled the leaves of the trees. Strange, thought Shelley, how she had not noticed it before. Now it seemed overwhelmingly present. Someone let off a loud fart-that was the baked beans for supper! Giggles rippled around the campfire before the quietness of the woods settled again. Several sort of birds were calling: whistles, twits, songs, and then the hoot of an owl. Despite all the sounds she still thought of it as 
silence . . . and it felt good to listen.

Over the next few days, Ms. McKay asked them to be aware of the smells around them (not after you feed us baked beans again, Shelley said to herself ). The woods smelled . . . how would she describe it . . . yes, they smelled green. Damp, fresh, clean, fragrant ... and definitely green. She would crush some different leaves between her fingers as she walked, letting the aroma waft toward her nose. She liked the earthy smell of the soil as she lay so close to it in her tent at night.

"Have you ever discovered the tastes of the forest?" said Ms. McKay. "Nature lets you know what to avoid. Anything that is red or grows on thorny plants is likely to be poisonous. Just taste the things I show you." Yeah, your insurance is probably not up to having a poisoned kid on you hands, said Shelley's head. Ms. McKay pointed out leaves they could chew on (but not swallow) to experience the flavor, and wild fruits that were edible.

"Let us also be aware of our sense of touch," said Ms. McKay on the last camp night. "Our skin is our biggest sense organ. If you could peel it off and spread it out, it would cover two square yards." Gross, thought Shelley. "Let yourselves discover what tactile sensations you experience in the woods. Not just what you touch but what touches your skin, like the coolness of the breeze or warmth of the sun."

Shelley felt the ground as she slept on it at night, the smoothness and coarseness of tree barks as she passed, the texture of leaves as she crushed them in her fingers, and the difference between soft soils and rocky outcrops as she hiked over them. She came across another shiny beetle, caressed its silky back, and felt its delicate legs walking across her hand. She picked up a feather in the trail, drawing its softness between her fingertips.

Having always thought of herself as a city girl, Shelley surprised herself when she got back home. She wanted to go walking. She hadn't seen before how many lovely gardens there were down her Street or what a delightful little place was the park at the end of the road. As she walked she saw the colors in the gardens, smelled the fragrance of flowers in the air, felt the warm of the sun and the cool of the shade, and heard bird calls she'd not heard before ... and it all felt great.

Question 1: What was your favorite part of this story? Why?

Question 2: What feeling does this story remind you of?

Question 3: Did you like this story? Why do you think you like it? If you don't like it, why don't you?

Question 4: Do you like spending time in nature?

Question 5: What are your favorite aspects of spending time in nature?

Question 6: Can you explain the similar aspects of the section you composed and the story read?

Question 7: Did the story help you compose?

Question 8: How did it feel to compose this story? 
The Qualitative Findings

\section{The Findings on Participant 1}

\section{Story 1 and Participant 1's First} Composition

The first participant said that his favorite part of the story was that it had rained on the child with anger, turning into hail. Thus, there were difficulties and excitement in the story increased. He said that in a difficult situation, he could give up trying but he also said that if other people said he couldn't, he could keep on struggling. He said he had a sense of ambition in the story. He found the story funny and said that composing with it was a funny experience.
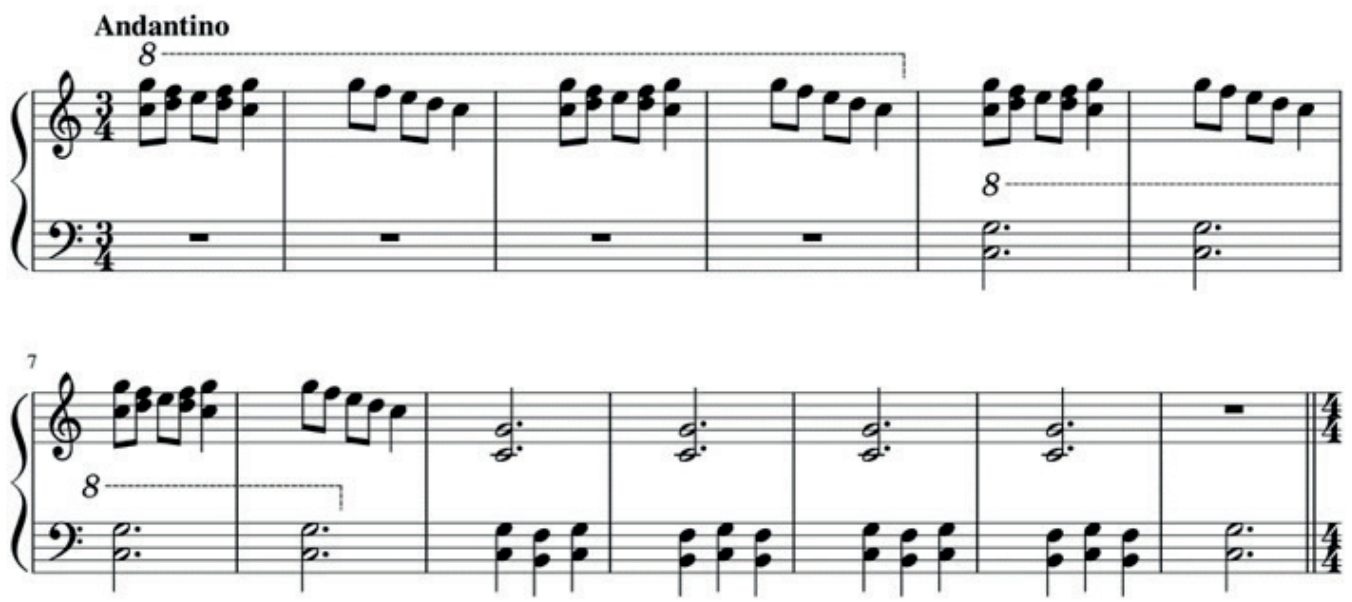

Notation 1. Participant 1: Composition section for chapter 1 of story 1

He said that he told us about the octave to the low octave. He stated increasing intensity of wind between that he wanted to point out that a storm bars 1 and 8 by going from the high came up between bars 9 and 13 .
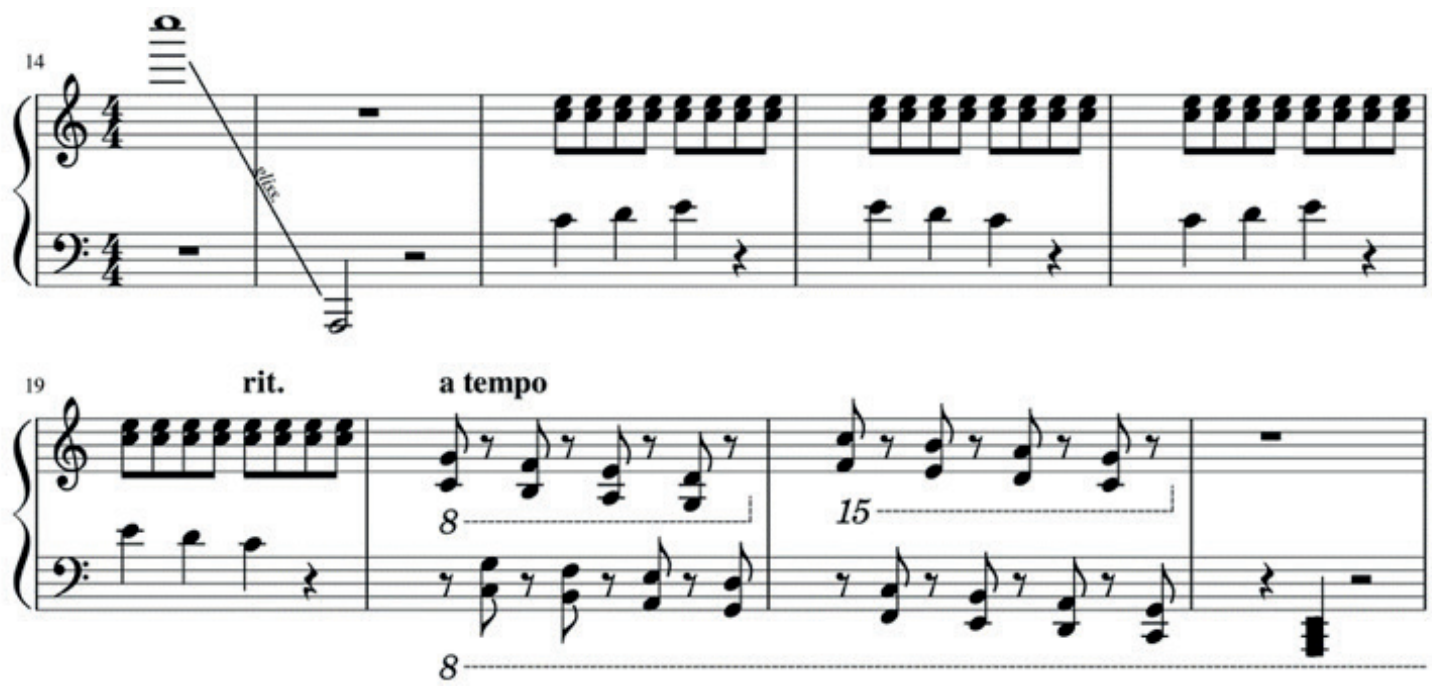

Notation 2. Participant 1: Composition section for chapter 2 of story 1 
He explained that the glissando in bars 14-15 explains the onset of rain. He stated that he wanted to convey that it was raining between bars 16 and 19 .
He said that between the 20th and 22nd bars he expressed the severity of the rain, with low octave. He described the hail with the cluster in the 22th bar.

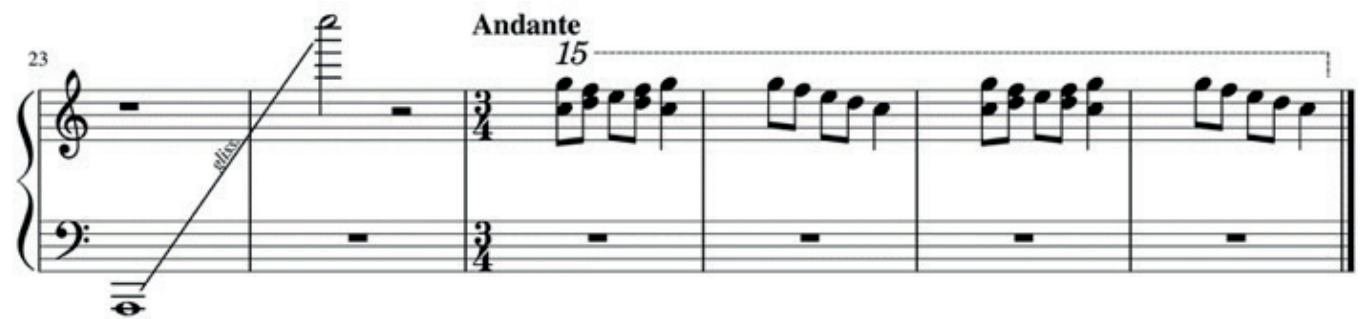

Notation 3. Participant 1: Composition section for chapter 3 of story 1

He said that the sun shines and raises the temperature with glissando in bars 23-24. Using high octave between bars 25-28, he said he wanted to tell the peace in the part of the sun at the end of the story.

\section{Story 2 and Participant 1's Second Composition}

The first participant stated that his favourite part in the second story was the part where the main character, the octopus, climbs the cliff with courage after going through challenging situations, and he felt joy in the story. He said that if he were the octopus, who had landed in the dark waters with the anchor, he would hold on the anchor and continue down so as not to be alone in the waters he did not know. But when the fish came to help, he said that he was not alone, so he would leave the anchor and get out of the dark waters with the fish. He said he dreamed that there were no creatures in the dark waters of the story. He recounted that he thought the octopus would be afraid to die alone, as there were no living creatures in these waters. He suggested that the octopus may have lost its home, and that it may have a family living near the surface. He said he found the story funny. He said that he didn't usually share his fears because his parent wouldn't understand him.
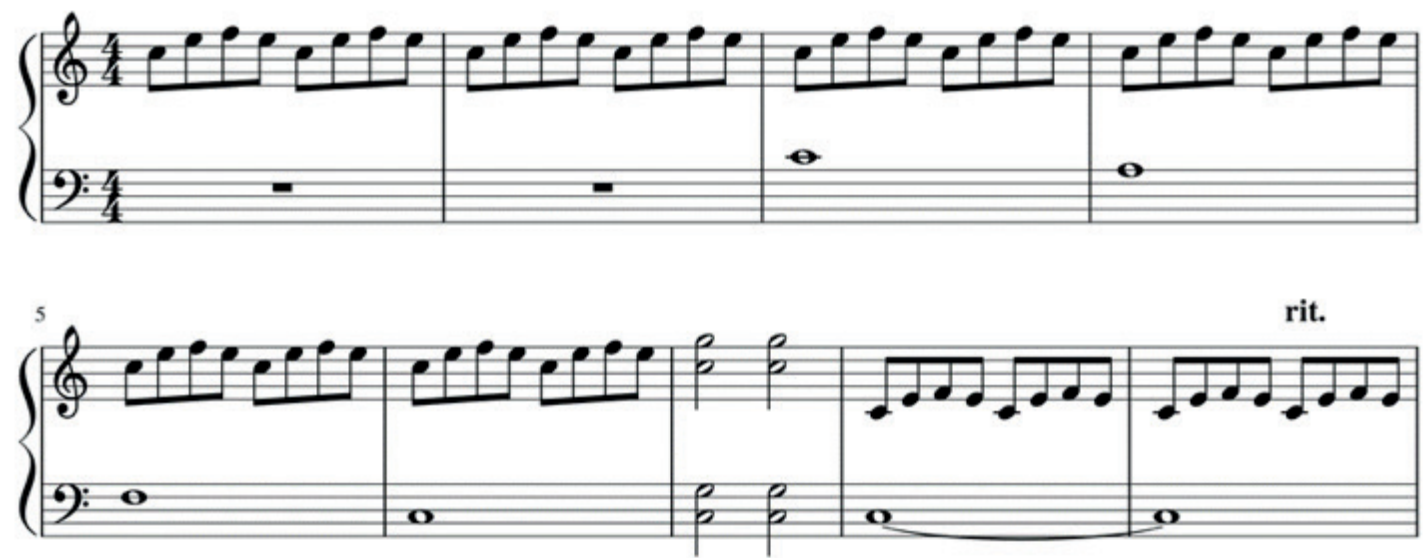

Notation 4. Participant 1: Composition section for chapter 1 of story 2 
He said that the octopus moved between the 1 st and 6 th bars to explore the environment. With half notes of the bar 7, he described the descent of the anchor and octopus.
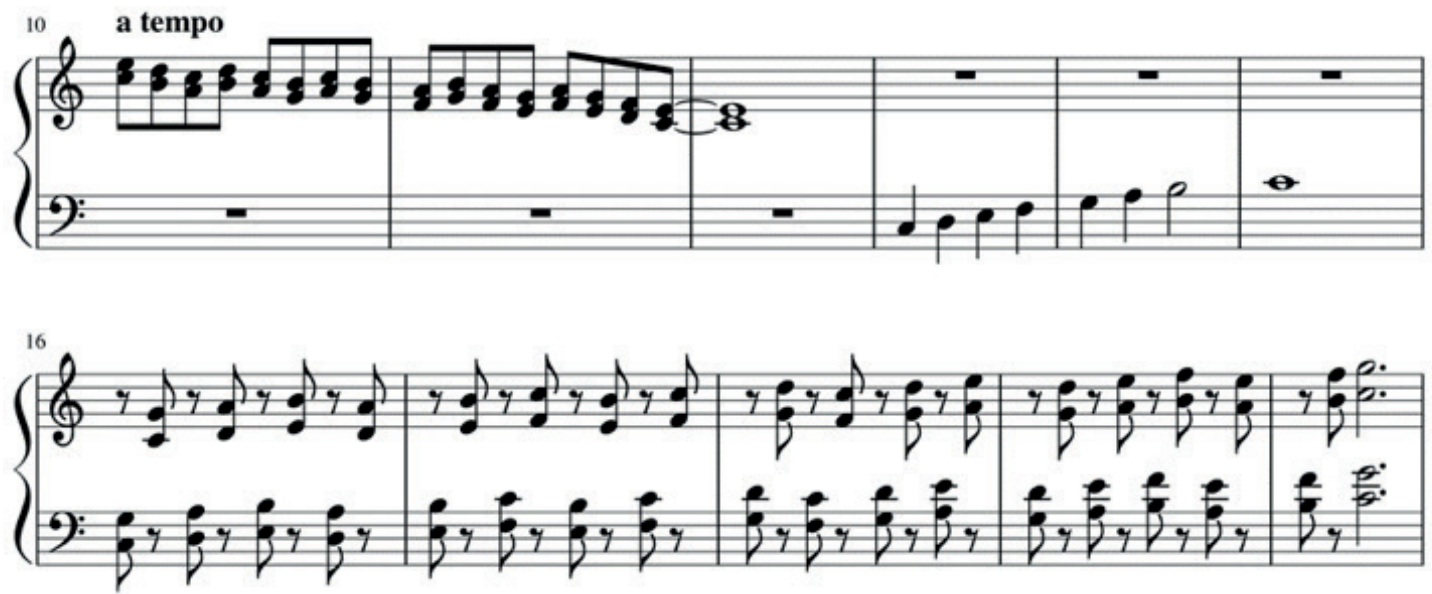

Notation 5. Participant 1: Composition section for chapter 2 of story 2

He said he wanted to tell us about the arrival of the fish in the 10th-12th bars. He stated that the 8 notes he used between bars 13-15 represented the number of octopus tentacles. The first participant explained that with these bars, octopus removes its tentacles one by one from the anchor. Although previous notes were quarter notes, he stated that the reason the $B$ note was a half note and $\mathrm{C}$ note was a whole note was because it was difficult for the octopus to pull its final tentacle from the anchor. He stated that he wanted to tell the octopus that it was floating to the surface between bars 16 to 20 . He explained the reason for using notes in a wavy, not linear fashion, toward the high octave as this was better suited to the way the octopus swims.

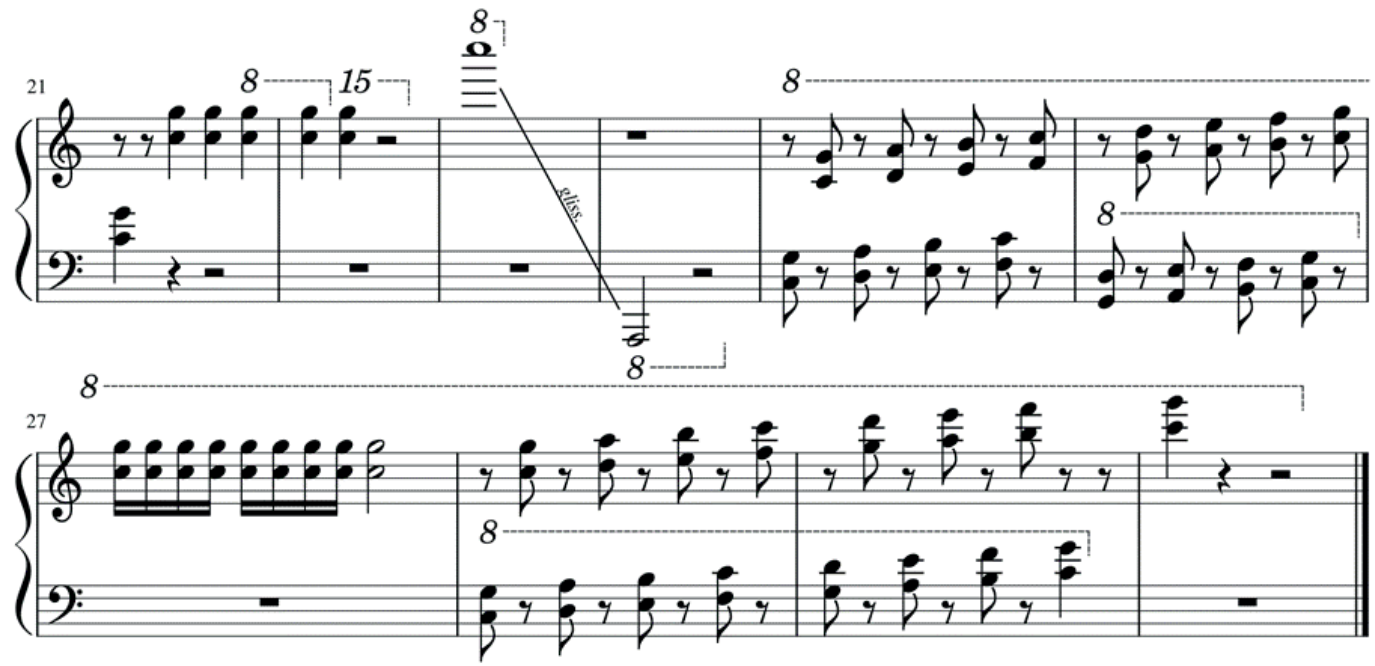

Notation 6. Participant 1: Composition section for chapter 3 of story 2 
He explained that the octopus swam alone in bars 21-22. He described octopus basking in glissando (bars 2324) and reported that the octopus was about to climb the cliff in bars 25-30. He remarked in the bar 27 that octopus was fatigued and hesitant when climbing.

Story 3 and Participant 1's Third Composition

In the third story, he mentioned that his favorite part was the one where the main character got into the tree trunk and felt at peace, and that he felt at peace in the story. He said that he liked this story because it was about nature. He stated that he likes to roam around nature and camp. He expressed that the greatest part of being in nature is being with birds and greenery.

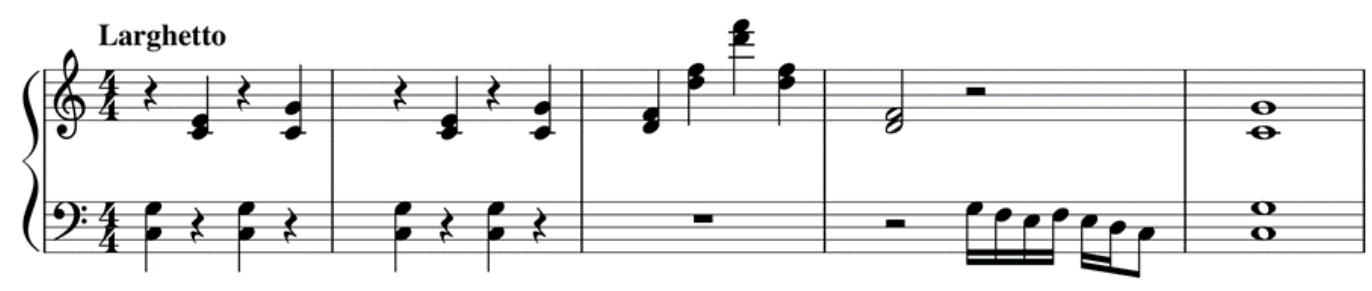

Notation 7. Participant 1: Composition section for chapter 1 of story 3

He stated that he wanted to convey the unhappiness of the main character in the first 2 bars. He stated that the reason for using the 3rd bar and half note in the 4th bar was to transfer the part in which the character enters the tree trunk. He stated that the reason for using the sixteenth notes and the eighth C note, in the 4th bar, was to describe the beetle's walking.
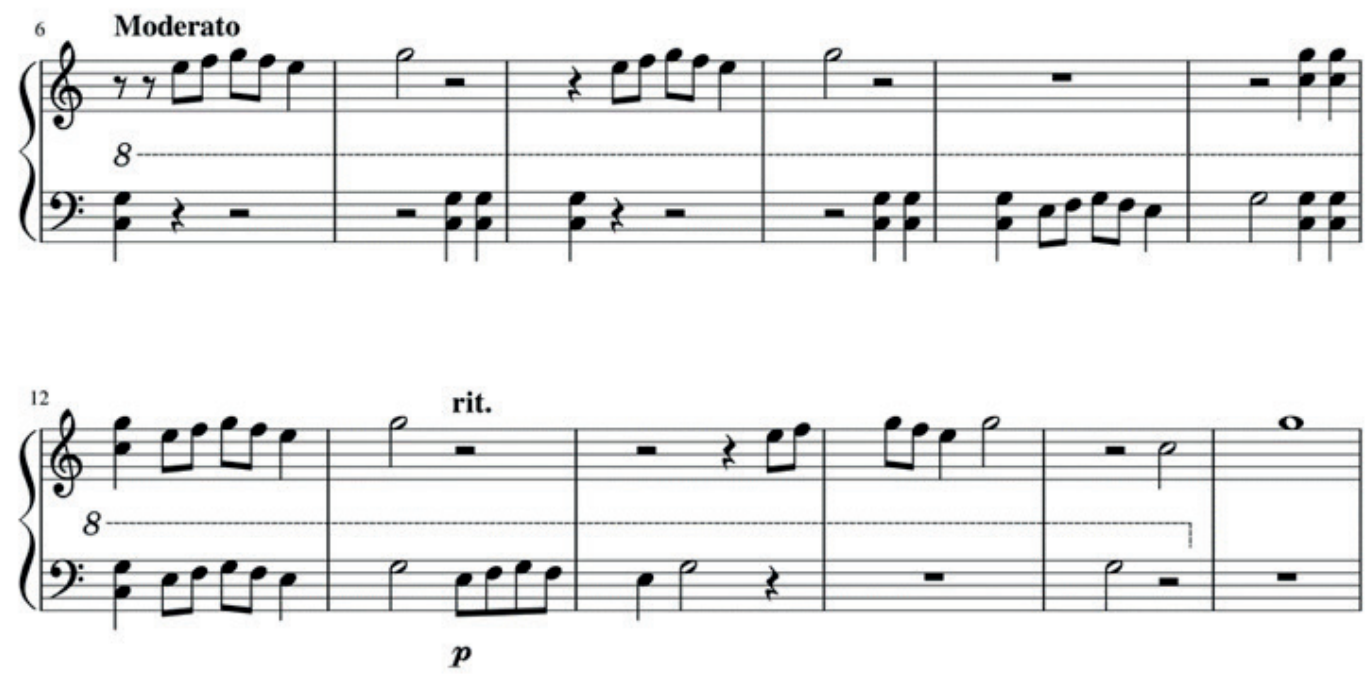

Notation 8. Participant 1: Composition section for chapter 2 of story 3

He stated that he wanted to convey the bars 6-17. peace of nature by using high octave in 

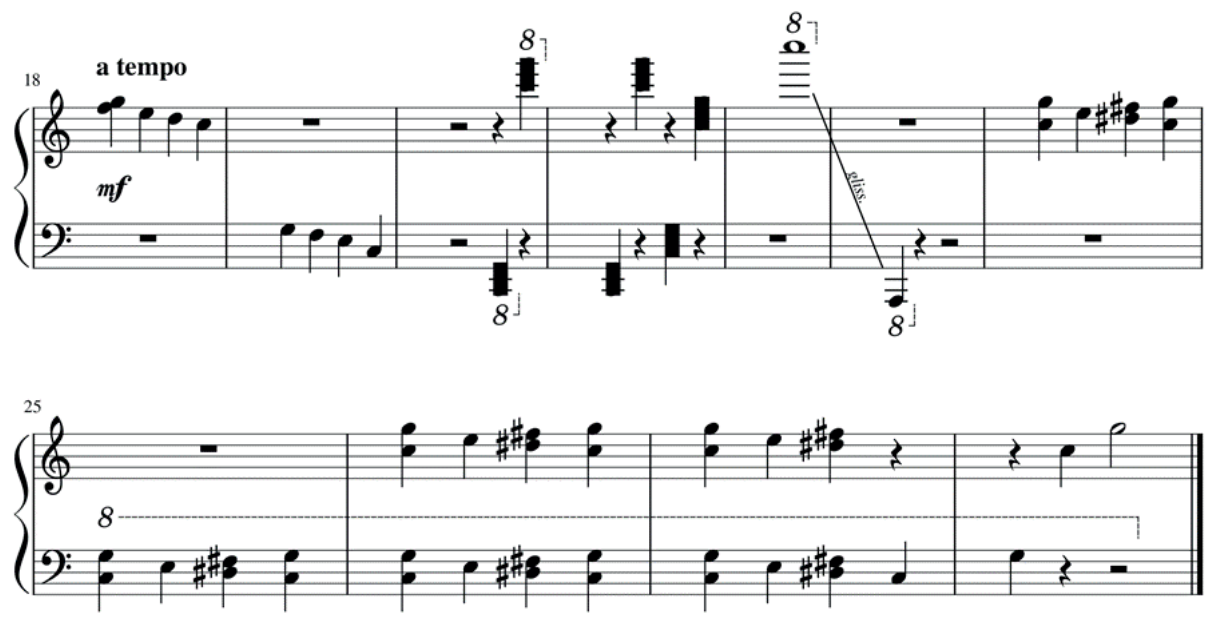

Notation 9. Participant 1: Composition section for chapter 3 of story 3

He remarked that the reason he used clusters and glissando in bars 20-23 was to express the sense of touch in the story. He stated that he wanted to convey a sense of curiosity and change in bars 24-28.

He stated that composing without stories makes him feel more free, but that composing with the story is also funny and that he wants to experience composing in both ways. He said stories helped him compose music.

Findings on Participant 2

\section{Story 1 and Participant 2's First}

\section{Composition}

The second participant suggested that if
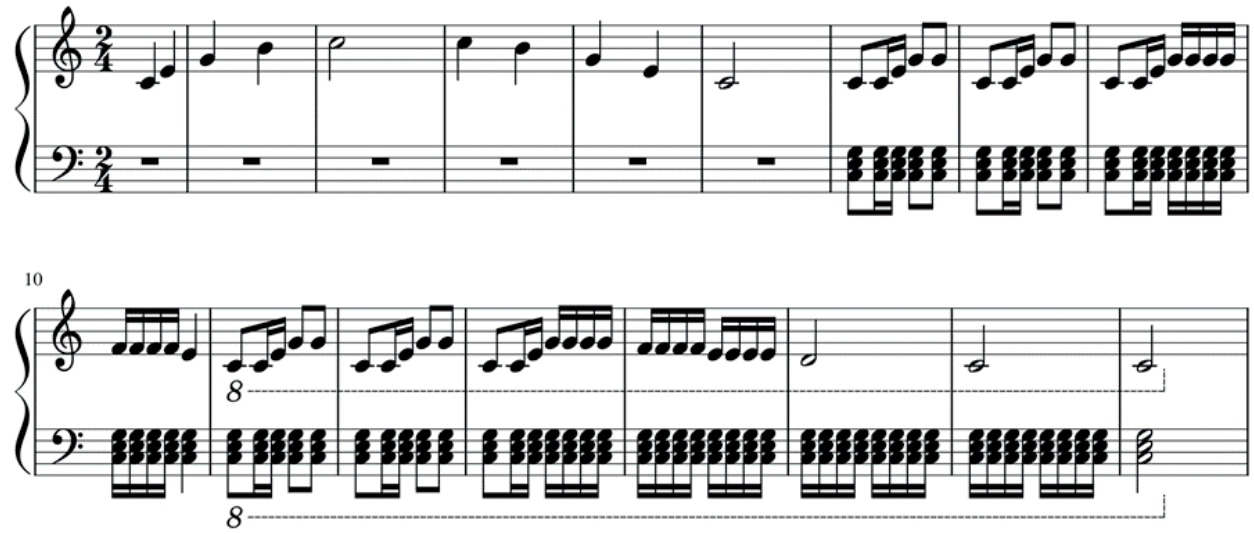

Notation 10. Participant 2: Composition section for chapter 1 of story 1 
She reported that the wind was calling calmly the child between bars 1-6. She said that the reason for the low octave between bars 7 and 17 was because the wind increased its severity. She stated that the melodic passage between these bars was a work that she had previously composed for her piano teacher.
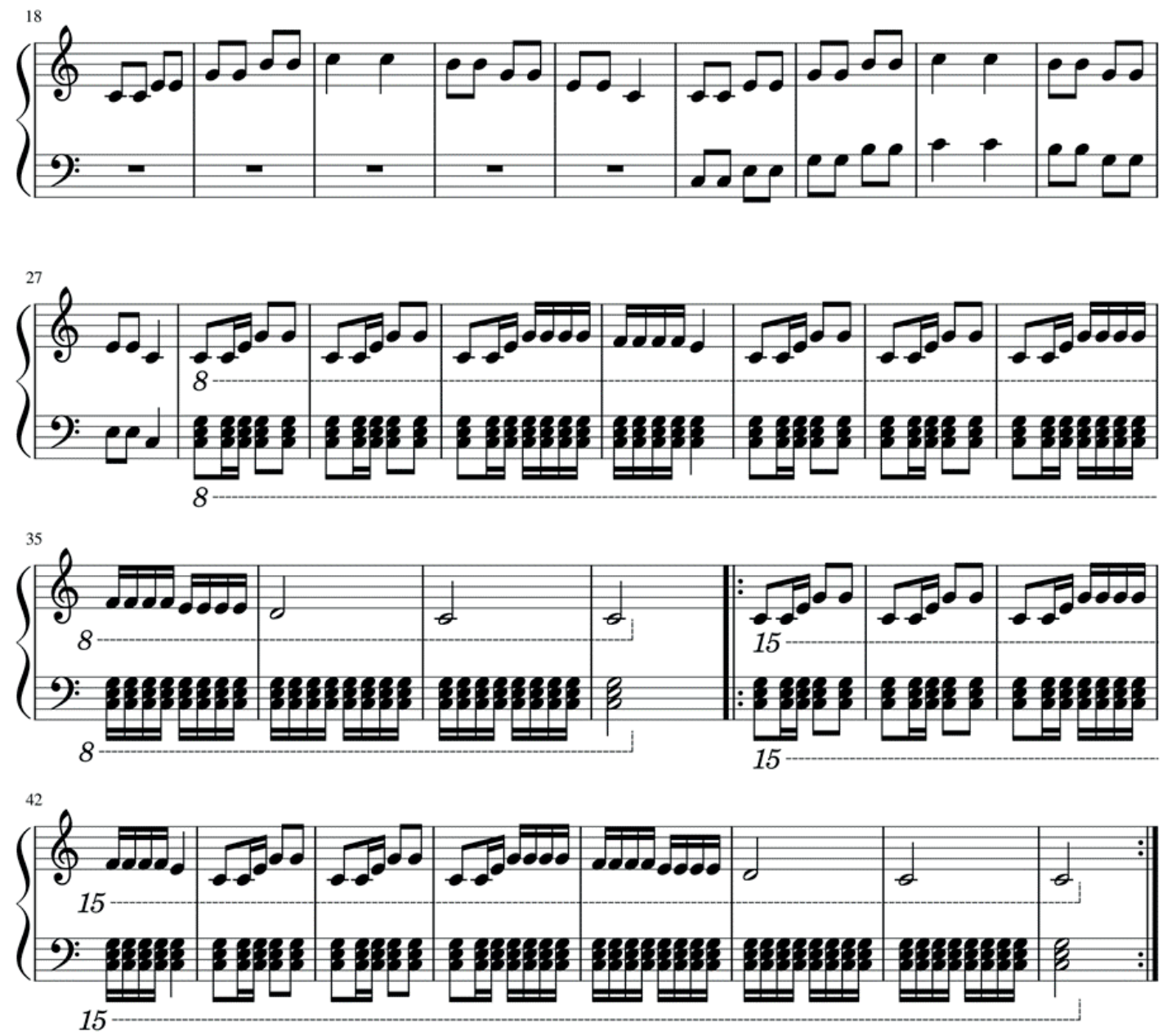

Notation 11. Participant 2: Composition section for chapter 2 of story 1

She said that, between 18th and 27th bars, the rain appealed to the child calmly. The second participant chose to use the passage between bars 7-17 of the first section in bars 28-49. She also stated that she prefers to pass the low octave in order to convey the severity of rain between bars 28-38. She said that the lowest octave between the 39th and 49th bars was to describe the hail. 

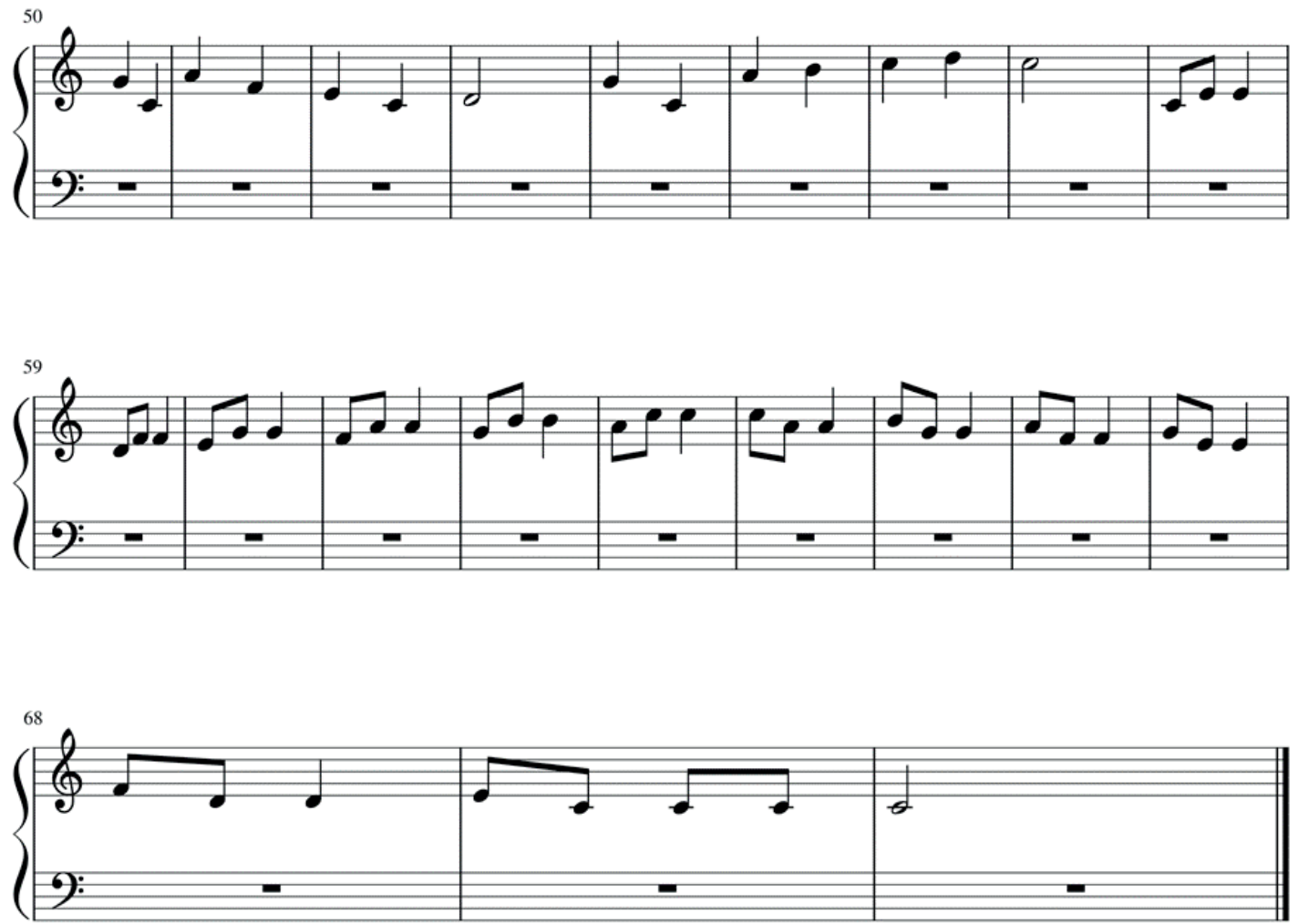

Notation 12. Participant 2: Composition section for chapter 3 of story 1

She said she wanted to convey the victory music of the sun in bars 50-57. She stated that she wanted to express the fact that the child took off his jacket between bars 58 and 68 . She stated that the consecutive $C$ notes in the 69th70th bars represented the child walking happily.

\section{Story 2 and Participant 2's Second Composition}

She asked what would happen if she didn't like the story before the second story was read. The teacher explained that this was a research and said that it was important for the participant to express her true opinion. She said that if she were the octopus, who had landed in the dark waters with the anchor, she would hold on the anchor and continue down because she would already be in the dark waters. But when the fish came to help, she said that if she was to, she would just drop the anchor, move on and get out of the dark waters. She said her favorite parts of the story were octopus getting out of the dark waters and fish encouraging it. She said that she loved the story, and concluded that with courage, anything could be done. When asked what she did when faced with situations she was afraid, she said that she shared her fear with her mother and her mother encouraged her. 

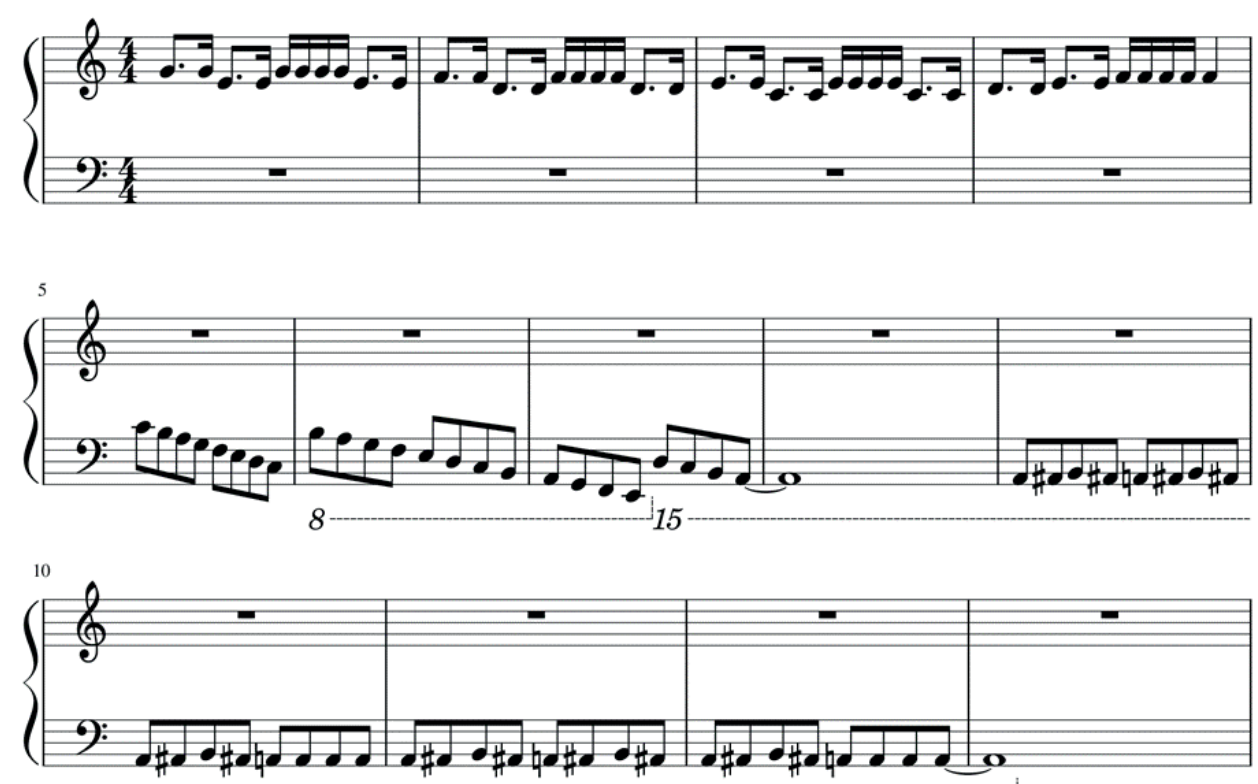

15

Notation 13. Participant 2: Composition section for chapter 1 of story 2

In the 1st line, she recounted the octopus the bottom. In bars 9-13, she said she having a cheerful day. Between the 5th and 8th bars, by going down to the low octave, she said she wanted to tell the octopus going down with the anchor to chromatic pitches for this.
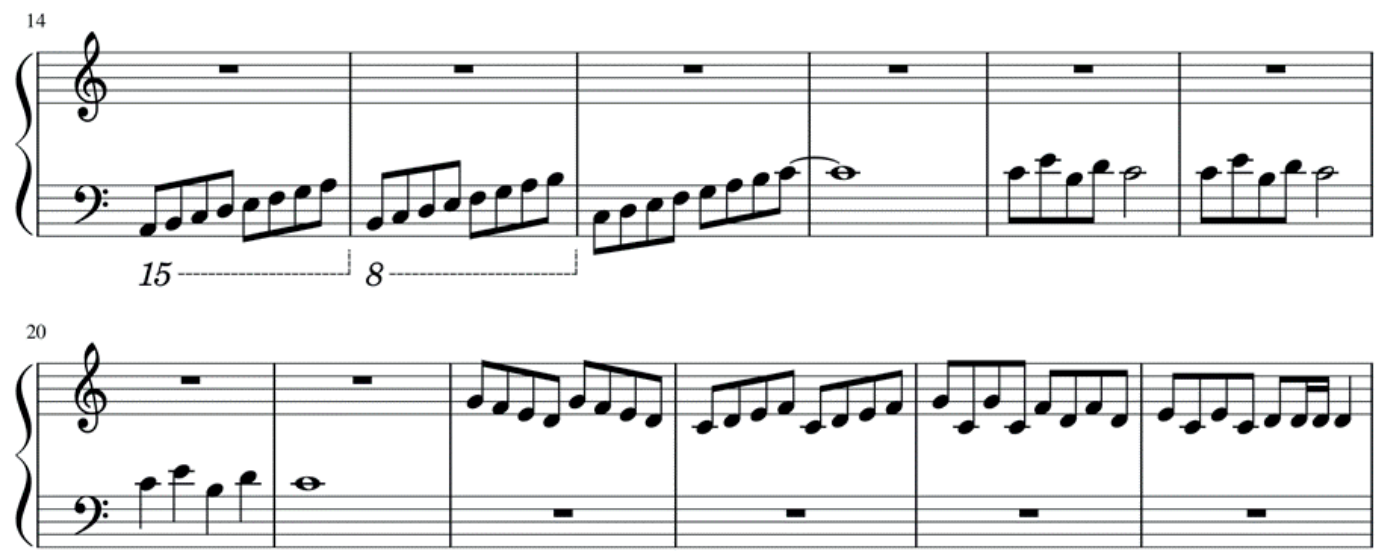

Notation 14. Participant 2: Composition section for chapter 2 of story 2

Between the 14th and 17th bars, she went up to the high pitches and said she wanted to tell about the arrival of the fish. She said she wanted to tell us between the bars 18-21, the part where the fish encouraged the octopus. She said wanted to express the octopus being in danger when it was tightly wrapped in the anchor, and she mostly used 

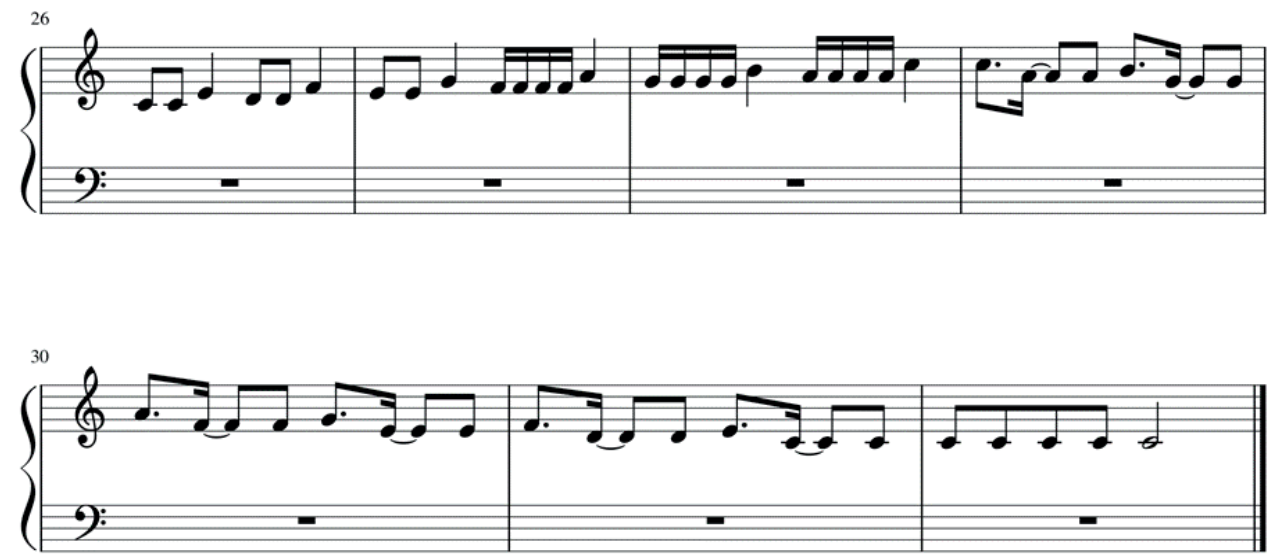

Notation 15. Participant 2: Composition section for chapter 3 of story 2

She reported that octopus swam freely between bars 26-28. She expressed her desire to describe the octopus dancing in bars 29-31. She said that the consecutive $C$ notes in the bar 32 described a happy ending.

\section{Story 3 and Participant 2's Third Composition}

She suggested that her favorite part in the third story was that the main character moved on with happiness at the end of the story. She stated that she was happy when people were happy. When asked what feeling the story reminds her of, she said she felt sorry for the main character's position as her bag was heavy. She also mentioned that the feather touch of the main character reminds her of a delicate emotion. She said that she liked some parts of the story, but didn't like the fact that there was no action or excitement in the story. She stated that she likes to spend time in nature during the day, but not in the evening because she is afraid of wild animals. She expressed that the best part of spending time in nature is to reach out to the grass and watch the sky.
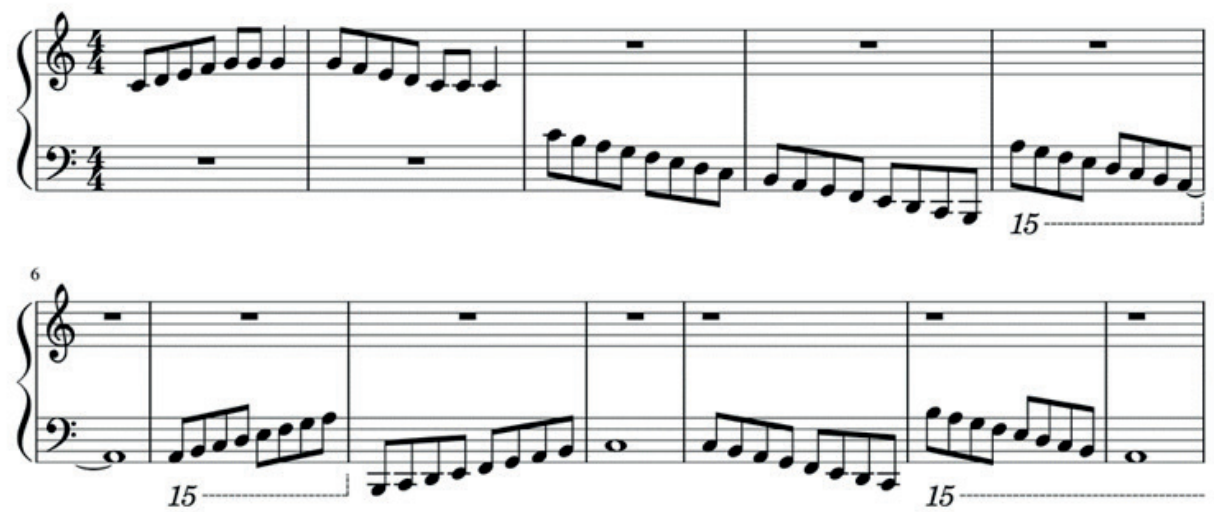

Notation 16. Participant 2: Composition section for chapter 1 of story 3

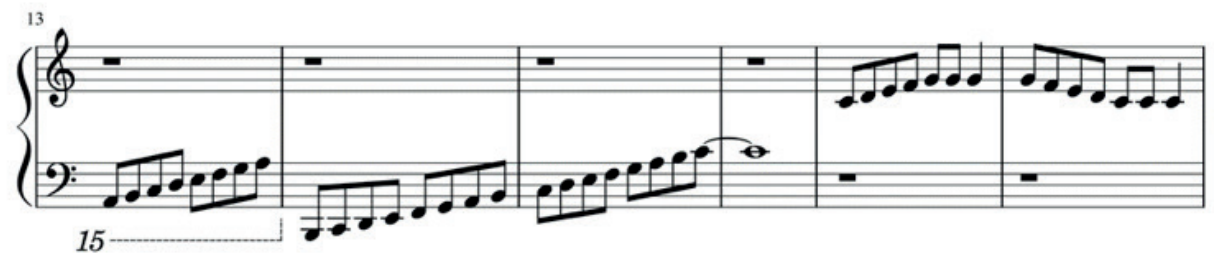


She expressed the nature walk of the main character in the first 2 bars. She explained that the reason she wanted to start the composition from this part of the story is that she wanted to start the composition in a smooth mood, which is why she used the hiking part initially. She stated that she expressed the main character walking by feeling the weights between bars 3-16.
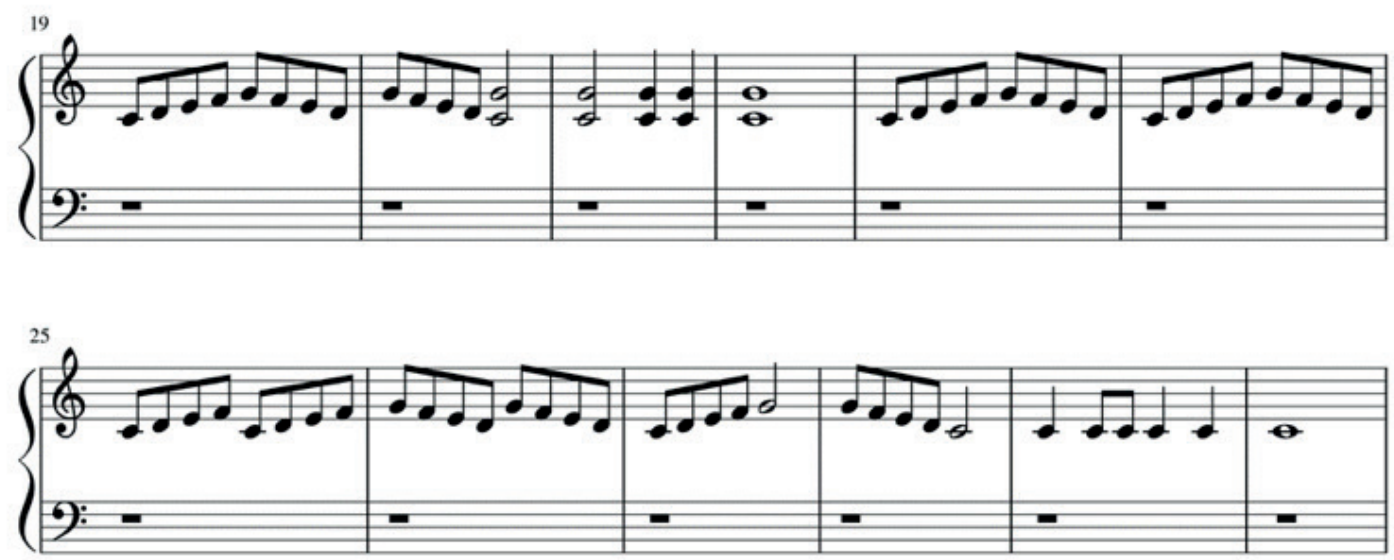

Notation 17. Participant 2: Composition section for chapter 2 of story 3

She stated that she wanted to express the main character's presence in nature between bars 19-22. In the 25th bar, she conveyed the main character's taste of the leaf and expressed the part where she smelled what was around in bars 27-28. With the consecutive $C$ notes in bars 29 30 , she expressed the main character's joyful passage through nature.

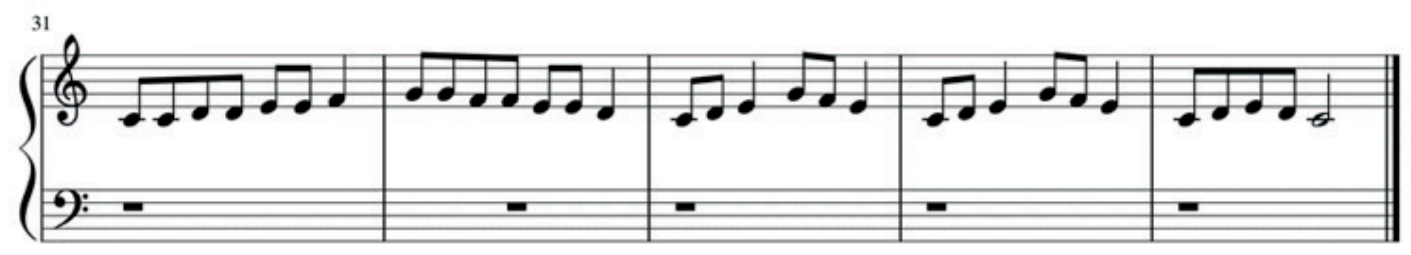

Notation 18. Participant 2: Composition section for chapter 3 of story 3

She stated that in bars 31-32, the main character returned home. She shared the voices the character had heard around when she returned home and expressed pleasure in the 35th bar.

She said that stories helped her to compose, she replied that she wanted her compositions to be recognized by everyone like Mozart and Beethoven and that stories inspired her to do so. She said that she wanted to let the world hear her compositions. The second participant often tried to use pieces she had already played during the composition process. The researcher encouraged her to create original compositions.

The second participant said her dream was to play pieces that were very difficult and could not be played by everyone. She mentioned that she wanted to feel talented and get approval from her parents. She needed to share with her 
teacher that her friends sometimes mistreated her. At the end of the study she indicated that she wanted to take another lesson with the lesson content during the research process.

\section{Findings on Participant 3}

\section{Story 1 and Participant 3's First}

\section{Composition}

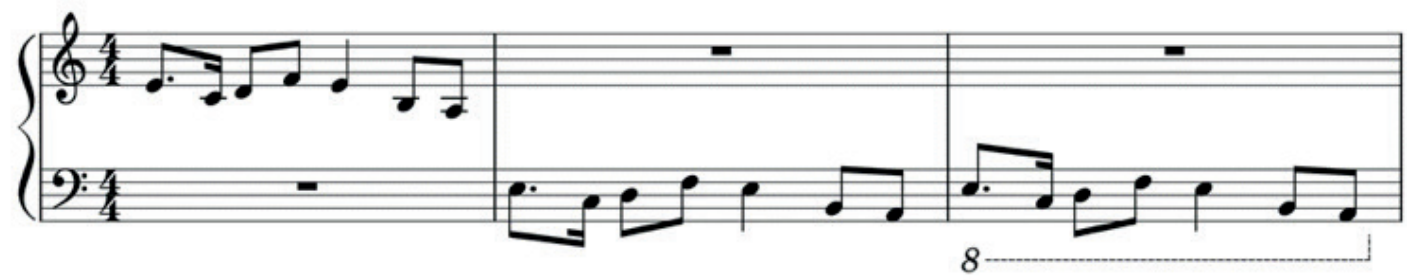

Notation 19. Participant 3: Composition section for chapter 1 of story 1

She said she wanted to reflect that intensity by going towards the low the wind was gradually increasing its octave.
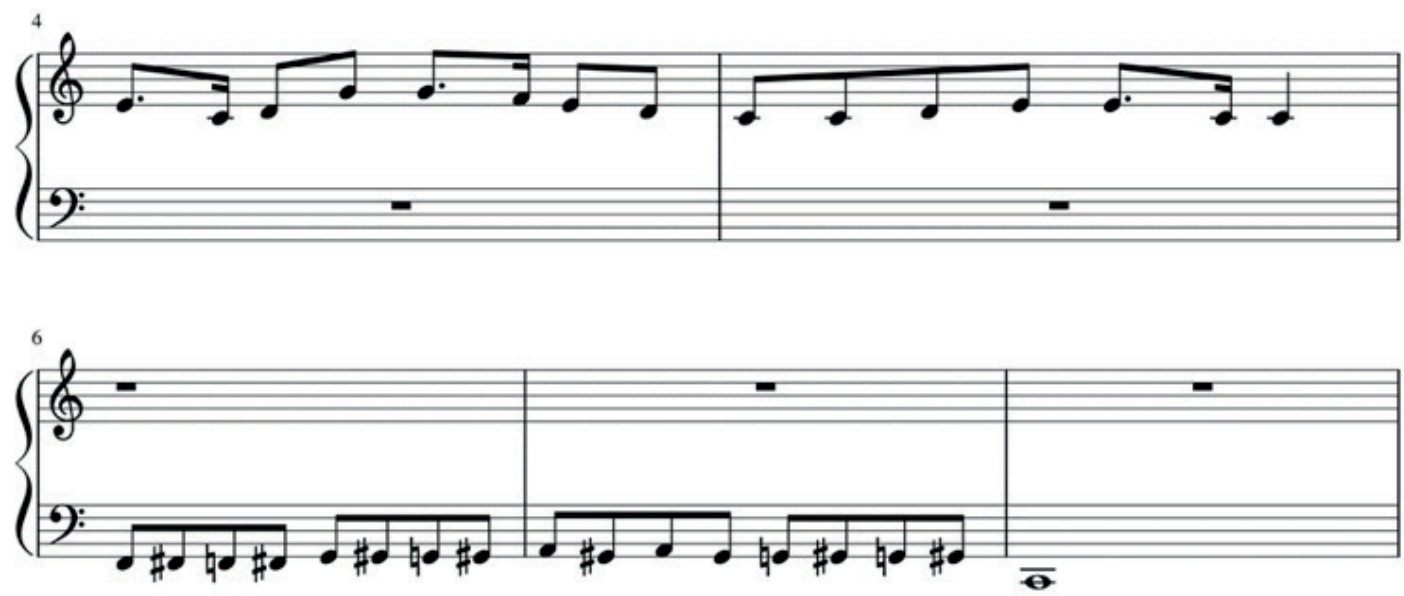

Notation 20. Participant 3: Composition section for chapter 2 of story 1

She stated that between the 4th and 7th bars, the rain grew stronger and she wanted to convey the hail with the $C$ note in the 8th bar. 

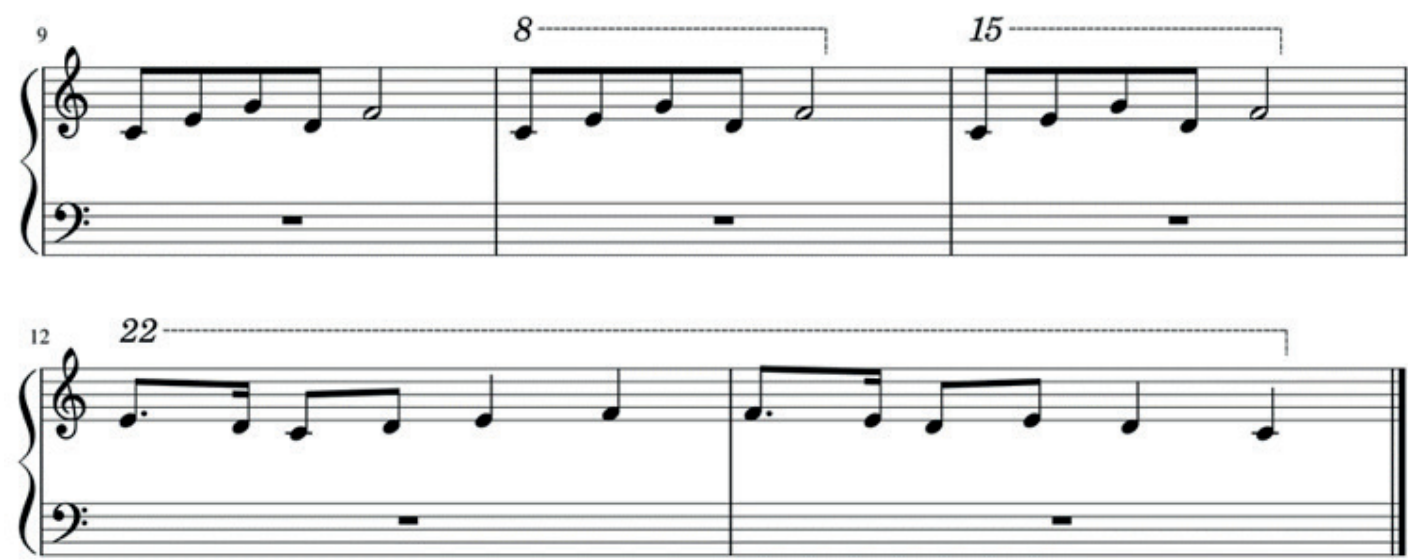

Notation 21. Participant 3: Composition section for chapter 3 of story 1

She said that the reason she went towards the high octaves was to express how the sun warmed up. She said that the $\mathrm{C}, \mathrm{E}$ and $G$ notes between the 9th and 11th bars describe the sun's rays and the $D$ and $F$ notes describe excessive light.

\section{Story 2 and Participant 3's Second Composition}

In the second story, the third participant said that she was glad that the main character, the octopus, was sad and that she did not like octopus. She said she would end the story the way the octopus would die. She also mentioned that while listening to the story, she had dreamed of disturbing the octopus, that she had dreamed of the octopus escaping her and that she enjoyed it. She stated in the story that the octopus flying would seem absurd to her, that such a thing cannot actually happen.

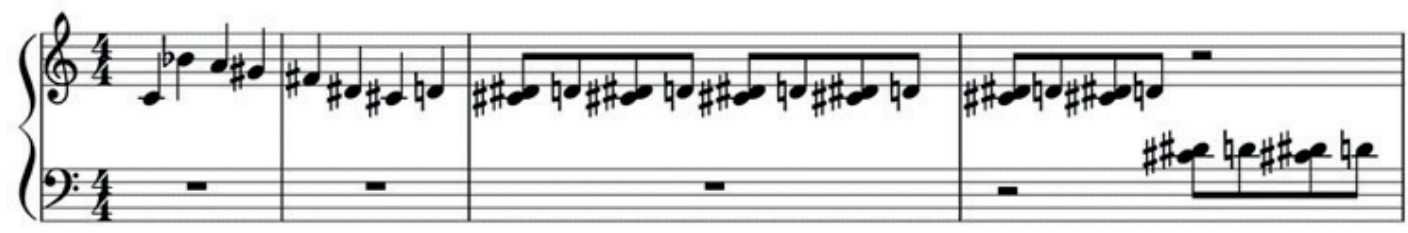

Notation 22. Participant 3: Composition section for chapter 1 of story 2

She described the octopus's fear of the stuck in the octopus. dark, and her vision of the anchor getting

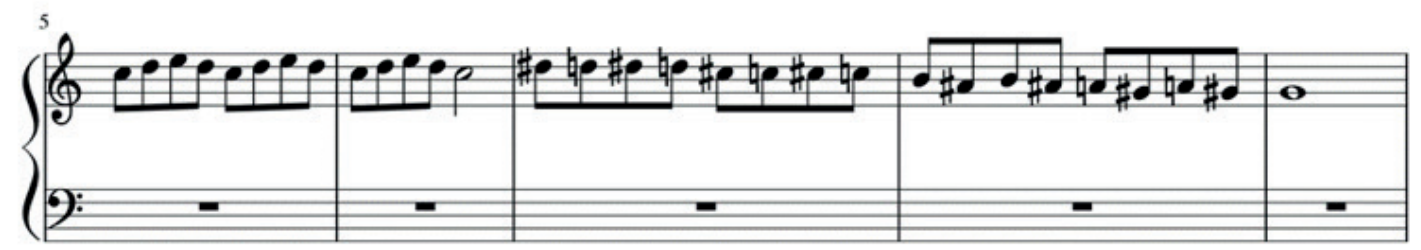

Notation 23. Participant 3: Composition section for chapter 2 of story 2

In this part, she wanted to describe the free of the dark waters. sense of rejoicing when the octopus was 

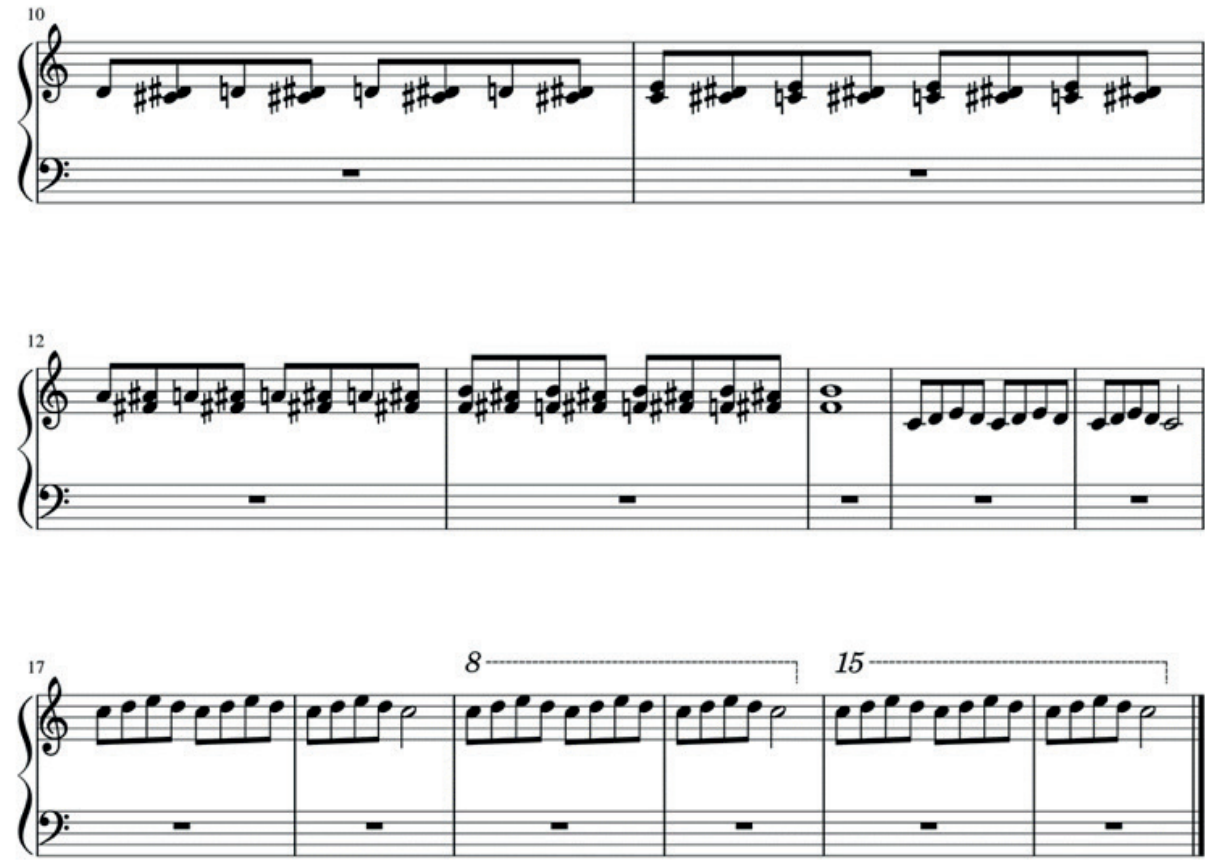

Notation 24. Participant 3: Composition section for chapter 3 of story 2

She stated that the reason behind this to see the beauty around her. She said move from the 15th bar to high octave is the story reminded her of a feeling of to describe happiness. change. She said that she liked the story

Story 3 and Participant 3's Third Composition

The third participant told that her favorite part in the third story was that the main character changed by beginning because she found it realistic. She says that she likes to take a walk in nature and play games. She said that her favorite part of spending time in nature was not being hurt when she fell on grass.
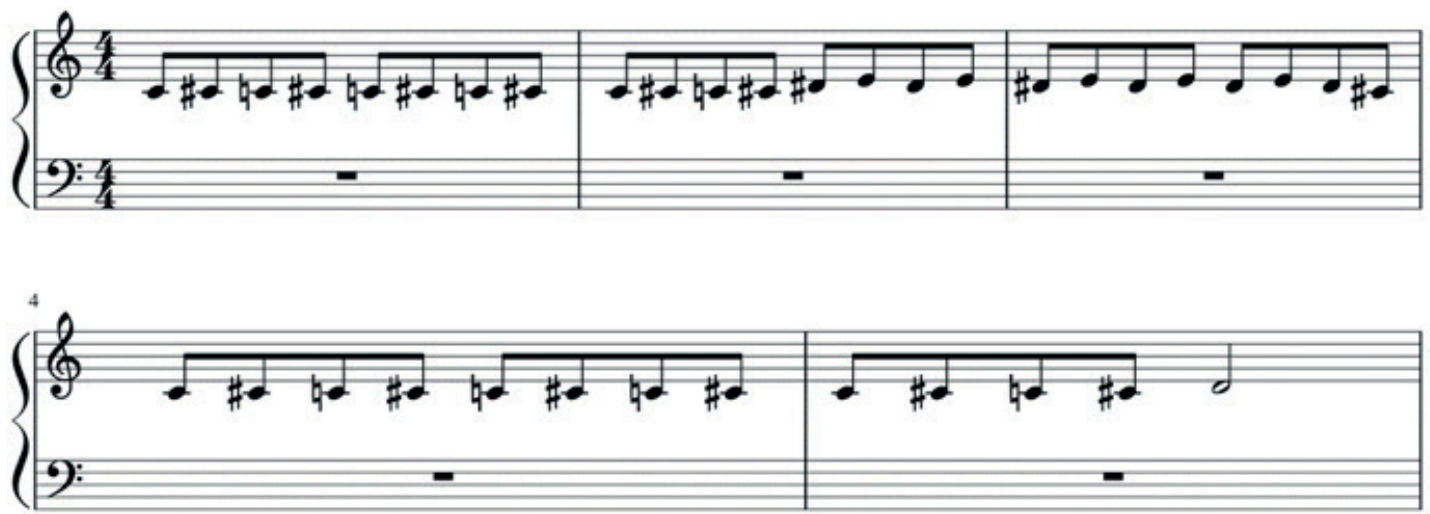

Notation 25. Participant 3: Composition section for chapter 1 of story 3

She recounted the anger felt by the between bars 1-5. main character carrying the heavy bag 

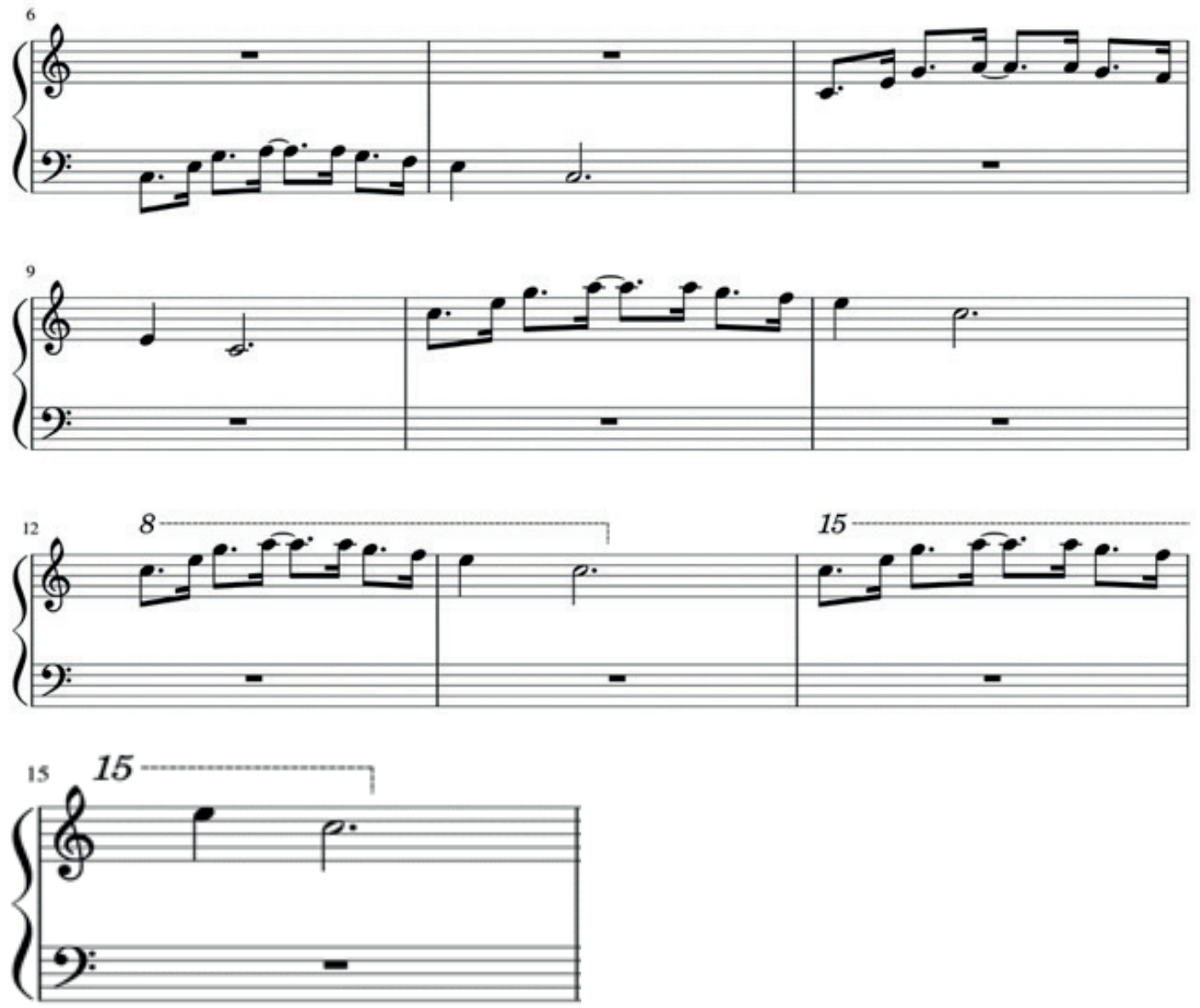

Notation 26. Participant 3: Composition section for chapter 2 of story 3

She explained that the leaves were flying between the 6th and 15th bars. She also said that the low and high pitches represented the protagonist walking, zooming in and out. 

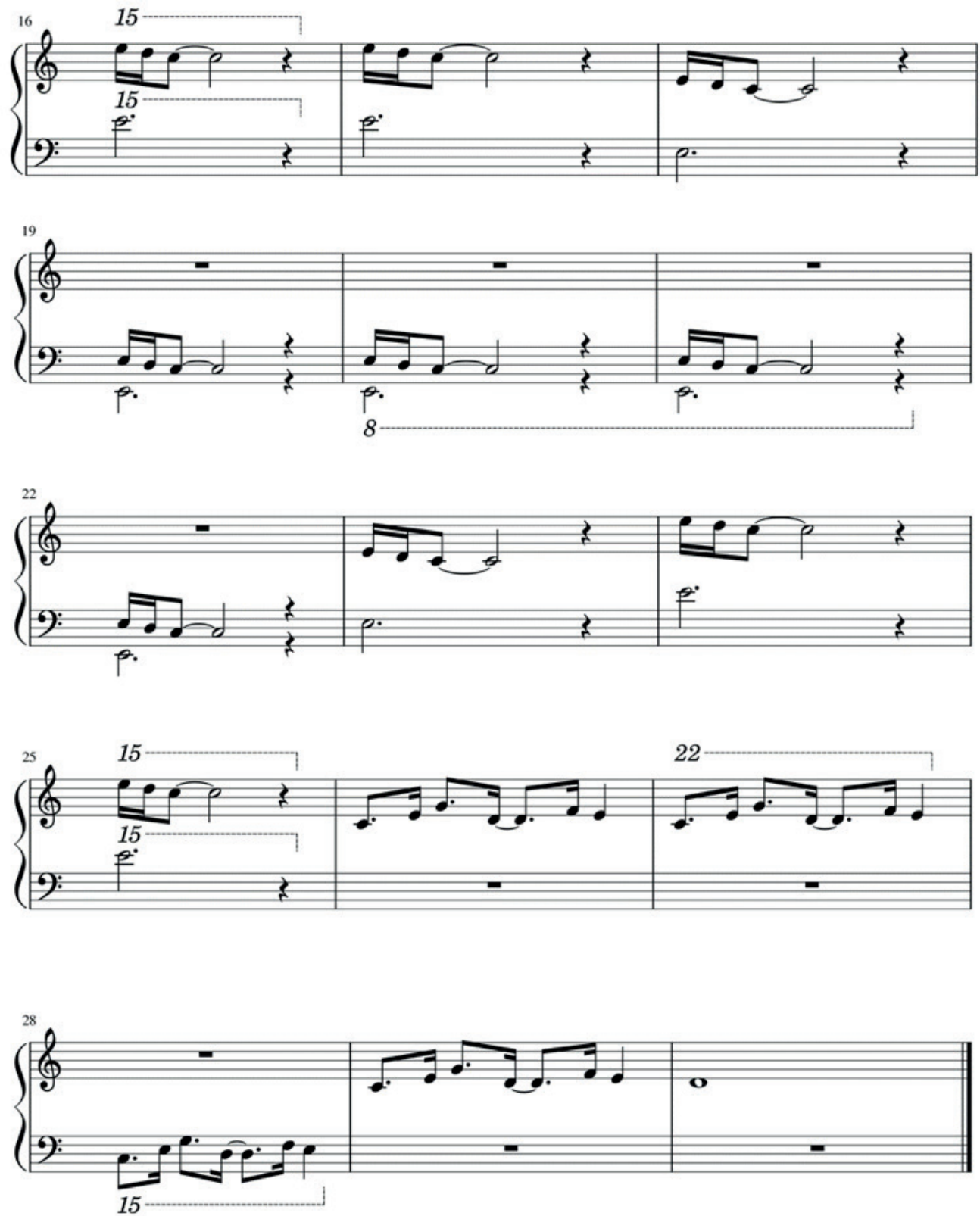

Notation 27. Participant 3: Composition section for chapter 3 of story 3

She stated that this section was not related her compositions. She said she would to the story and said that the melody fit the composition.

She said that she did not generally like to compose. But she said the stories helped her to compose music. She explained never choose to compose without a story. During the composition process, she got bored because she had difficulty creating melodies, but she said that listening to the final version of her compositions made her that she used the emotions in stories in happy. 
The Conclusion and Suggestions for Further Research

The first participant indicated that he liked the part of the first story where where difficulties came up. He said that while he is prone to giving up in the face of challenges, being labeled as unsuccessful by others could motivate him to overcome the difficult situation. He said that there was a sense of ambition in the story. He noted in the second story that his favourite part was the one where the main character was encouraged after going through difficult situations. He explained that if he were the main character, he would be encouraged to get out of the difficult situation when he was not alone. The first participant dreamed that the main character was afraid to die alone in the frightening place he was in. In the third story, he described his favorite part as the one where the main character felt at peace by entering the tree trunk alone.

Unlike the other participants, the first participant has used clusters and glissandos in his composition. He preferred to use more polyphonic arrangements than other participants. He reflected the events of the chapter of the story in various melodic forms in the relevant composition section. Therefore, various melodic forms are often seen in composition sections. It has been determined that he frequently depicts the situation in his compositions. For example, he explained the warmth of the sun with the scaling glissando and conveyed the tree trunk with descending and ascending notes forming a semicircular shape.

The second participant said that if she were the author, she would have finished the end of the first story in such a way that no character would fail. Her conclusion from the story was that winning or losing didn't matter. She stated that her favorite part in the second story was the encouragement of the main character by its friend and its rescue from the difficult situation it was in. In the third story, she said that she was happy when people were happy, so she liked that the main character was happy at the end of the story.

It has been observed that the second participant wanted to use the pieces she had previously played in her compositions during the research. She stated that she dreamed of her own compositions being recognized by the world. She stated that she wanted to play hard works that not everyone could play, to be approved by her parents. She felt the need to share with her teacher the bad attitude of her friends towards her.

The second participant chose to use her work, which she had previously composed for her teacher, in the first and second sections of her first composition. It has been observed that she often creates melodies in the five-finger position, and in her compositions she uses descending and ascending scale progressions over long measures. Apart from the composition created for her teacher, it was determined that she used monophonic order in her compositions. She never used the black keys.

The third participant said that her favorite part in the first story was the gentle behavior of the sun character. In the second story, she expressed her joy at the sadness of the main character, the octopus, because she did not like octopuses. She stated that she wanted the octopus dead. In creating the first section of her composition, she stated that she imagined that the anchor was stuck in the octopus. In the third story, 
she stated that her favorite part is that the main character changes by seeing the beauties around her.

It was determined that the third participant frequently used chromatic pitches in her compositions. Except for the third part of her third composition, she preferred to monophonic order in her compositions.

All participants stated that the stories helped the composing process. It was determined that all participants had a positive feeling about the composing process along with stories. Although the first participant said that composing without stories made him feel freer, he also said that he found it funny to compose with the story. He stated that he wants to compose in both ways in the future. The second participant stated that the stories inspired her. She conveyed her desire for her compositions to be recognized by people. She stated that she wanted to reexperience the process of composing with stories. The third participant said that she used the emotions in the story during the composition process. She stated that she did not like to compose in any way, as she found creating melodies challenging. However, in this research, she said that when she listened to his compositions through the Musescore program, listening to the finished compositions made her happy. She stated that if she was going to compose, she would definitely prefer to do it with stories. Based on the data of the first and second participants, it can be thought that composition works with stories are a factor that can increase the motivation of children, since they are found entertaining and inspiring.

The process of creating composition with stories can be used as a method for a child who likes to compose. Considering the data of the third participant, it may be useful to understand the reasons why children do not like composition. Children are not obliged to compose in piano lessons. However, if it is planned to do so, the child who has difficulty in composing can do small composition works before such studies and explain how to solve the technical problems he/she encounters, which can increase the motivation of the child for the creative process.

There have been cases where the situation or behavior that contrasted with the participants' own behavioral characteristics took place in their favorite part of the story. The first participant stated that he likes to have difficulties in the first story, but he is not inclined to make an effort in the face of difficulties. The third participant said that in the first story, she liked the kind behavior of one of the main characters very much, but she would have been rude if the character was herself.

Each child's answers to questions about stories differed. The participants' interpretation of the emotions of the characters in the story and their feelings about the events in the story differed. In the second story, the second participant was upset about the condition of the character in distress, while the third participant was happy. In the first story, the first participant's favorite part was the appearance of a difficult situation in the story, while the favorite part of the third participant was the gentle behavior of the main character. The second and third participants said that when they experienced frightening situations, such as the main character in the second story, they shared their fears with their parents, while the first participant said 
that he did not tell anyone about these situations and that he felt that his parents did not understand him. It has been found that questions about stories can help the teacher get to know the students better by recognizing their perspective, interests and feelings. Therefore, it was thought that the questions asked through the story could be important for strengthening the bond between the student and the teacher and for the formation of a therapeutic relationship, and therefore the motivation of the students could increase.

When answering the questions posed to them, the students imagined events that were not in the story and reflected these dreams in their compositions. Assuming that the questions asked encourage students to dream, it can be considered that these questions help students to participate more actively in the storytelling process. Therefore, students may have the opportunity to understand, explain and convey their psychological reactions more freely to their compositions. It can be considered that the teacher may also have the opportunity to get to know the inner world of the student more closely.
Participants generally said that they liked the stories read during the research process. Only the third participant said that she did not like the first and second stories because she did not find them realistic, and the second participant stated that she did not like the lack of action, even though there were features she liked in the third story. It can be thought that understanding the story preferences of the students by asking questions may have a facilitating effect on the selection of other stories in the education process. Thus, it is easier to choose stories suitable for students' interests in the process.

When the stories were divided into chapters, it was ensured that the students reflect more on the mentioned event and transfer the situations and events to the composition process. It can be thought that the method of studying stories by dividing them into chapters opens more space for students to express their psychological reactions to the story by reducing their cognitive load, and in this context, it can be thought that it contributes positively to the educational practice.

Table 2. Summary of the research

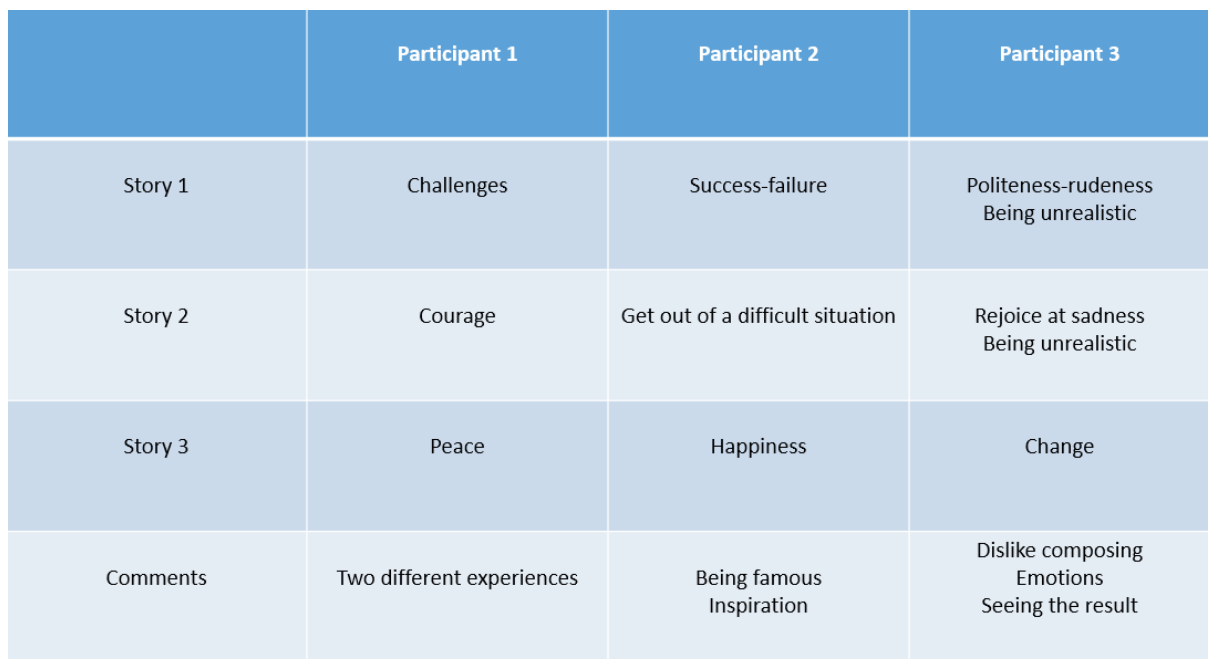


It was determined that there were differences in the way the participants reflected the situations in the story in their composition, as well as similarities. In the composition of the first story, all participants went from high octave to low octave to convey the strengthening rain and wind. They used high octaves for the part where the sun emits its warmth.

It was determined that the participants preferred to transfer certain events or emotions from the story chapters to their compositions. Except for the third composition of the third participant, all the participants used their favorite part of the stories in their compositions. There were also cases where the participants' favorite parts of the story were used only by these participants in their compositions. As an example, the first participant, unlike the other participants, in the third section of his second composition, used his favorite part of the story, the octopus courageously climbing the cliff. In the third section of the first composition, the second participant, unlike the other participants, used her favorite part of the story, the boy taking off his jacket. In the second section of the second composition, the second participant, unlike the other participants, expressed how the fish, one of her favorite parts of the story, helped the octopus. Apart from their favourite story sections, different choices were made among the participants. The second participant, unlike other participants, in the first section of the second composition, added to her composition the dangerous condition in which the octopus was found while clinging to the anchor. The third participant chose to create a composition section that was incompatible with the story, unlike other participants, in the third section of her third composition. Based on these data, it is thought that it is important to create a free space for children in story-oriented composition studies with children. In this research, although the stories are divided into chapters to facilitate composing process, the participants are free to choose which details of these story chapters to use in their compositions. It was thought that students should not be restricted from using specific events in the stories in their compositions. The events and emotions that students relate to in the story are different. It was thought that allowing them freedom to reflect these and giving them more choice could increase the motivation of the students.

During the research process, although each participant was given the same amount of time, the completion time of the composition varied. While the duration of the first participant was sufficient, for the second participant it was not enough, and for the third participant it was too much. Given the use of this study as a method, it may be more appropriate not to impose a time limitation on students. It can be considered that working on only one story chapter within $40,45,50$ minutes of piano lessons may be more suitable for the concentration time of the students.

This study is a preliminary research for the master's thesis titled "The Effect of Therapeutic Storytelling on The SelfEsteem and Social Anxiety Level of Piano Students Between the Ages of 6 and 12". It was thought that this preliminary study would support the thesis and method creation process in order to investigate 
the emotions that therapeutic stories evoke in children, to determine the ideal duration of the lessons in the thesis research, to examine the effect of dividing stories and compositions into sections, to see the result of the directives in the composing process, to determine the usefulness of the questions asked about the story and composition.

In the thesis, it is planned that therapeutic stories will specifically focus on self-esteem and social anxiety and be applied to piano students with low selfesteem and high social anxiety. Thus, the effect of therapeutic stories on children can be revealed more clearly. As a result of the studies, it was found that high self-esteem can positively affect self efficacy and performance anxiety. It was assumed that low self-esteem had a negative impact on the child's selfexpression and piano performance skills. It is planned to use therapeutic stories as a tool, assuming that high self-esteem will also positively affect the child's self-expression and piano performance skills. It is assumed that improving the self-esteem of piano students will contribute positively to the lessons. Social anxiety was also chosen because it is a subject related to self-esteem and supports the thesis. Thus, it was thought that the effect of therapeutic stories on the piano education process could be revealed more clearly.

In a part of the thesis, it is planned to investigate the use of therapeutic stories in piano education together with precomposed pieces. In music education, piano education methods for children include stories. For example, in the "Piano Adventures (2012)" and "John
Thompson's Easiest Piano Course (2011)" series, the lyrics of the pieces tell a story. The story is supported with pictures. Although these stories contribute to the child's understanding of music, they are simple and not therapeutic. This thesis study can also form a basis for research on piano education methods related to the use of therapeutic stories in music education.

Further research can be proposed to explore the use of therapeutic stories in association with other instruments, not just piano. In classrooms with many students, the contribution of therapeutic stories to music lessons can be explored. This allows for designing new methods with therapeutic stories according to the possibilities of different instruments or classroom environments.

In this study, children gave various answers to questions asked during the story process such as, "How would you end this story?" and "How would you go on with the story from now on?" Studies can also be done with incomplete stories, assuming that students may be freer to express themselves when they form the end of the story.

Studies involving participants from different age groups can be done. If studies involving children, adolescents and adults over the age of 12 are carried out, the effect of therapeutic stories in this age group can be looked at.

Studies can be conducted involving more participants who investigate the effect of therapeutic stories on children who are particularly prone to aggressive, obsessive, etc. traits. Thus, the effect of therapeutic stories on children with 
different psychological characteristics can be investigated and contributed to the spread of stories in music and instrument education.

\section{The Limitations of the Study}

The number of participants in this study was limited to 3 piano students. Participants are students between the ages of 10 and 12 at Arsu Fine Arts Academy located in Kadıköy, Istanbul. The limitations of the method used in the research are the determination of the therapeutic stories in accordance with the age range, the preparation of the questions directed to the participants in advance, the duration of the lesson and the use of the piano to create original compositions.

\section{Acknowledgement}

During my five years as a piano teacher, I had the opportunity to work with many children. I have also worked with students with behavioral and psychological difficulties. Over the years, I have had the opportunity to observe these behavioural and psychological challenges that reduce productivity and motivation in piano lessons. I noticed the lack of an approach towards students with behavioral and psychological difficulties in music and instrument education. For this reason, I focused on the studies I had observed to be missing, and prepared this article as a preliminary study of my thesis work that I was planning to do.

I would like to thank my dear thesis advisor, Tan Temel, Associate Professor, who has always believed in me throughout the research process, who kept my motivation fresh with his supportive approach, and who has not spared his efforts. His open-minded approach to my thesis and research process, which focuses on art education, allowed this research to be carried out. I would like to thank our dear Psychologist, Msc. Elçin Biçer for her valuable contributions to the psychological side of the research and to the esteemed Sernaz Demirel Temel, Associate Professor, for her support and constructive comments.

I am grateful to the parents who allowed my students to take part in my research for their support. I would like to thank my esteemed students who participated in the research process. I would like to thank the Arsu Academy of Fine Arts for their supportive approach.

I would like to thank Hasan Said Tortop, Associate Professor, for his contributions in creating the structure of the research and designing the summary, and for sharing his knowledge with me. I would like to thank Esra Üzmez, psychologist, Msc. Serra Hoșcan Gülseren, who supported me in the English translation of the article, and my dear friends Mustafa Avşar, Asistant Proffessor and Burak Tan, who have made their contributions with their useful comments.

I would like to extend my endless thanks to my friends who believed in me during the research process and to my esteemed family who have always stood by me with their support.

\section{References}

Bauer, M.S., Balius F.A. (1995). Storytelling Therapy and Curriculum for Students with Serious Emotional Disturbances. TEACHING Exceptional Children, 27(2), 24-28.

Baumgartner, B.W. (1996). Folktale 
Storytelling as an Education Tool With Possible Therapeutic Implications. (Doctoral dissertation). Available from ProQuest Dissertations \& Theses Global database. (UMI No. 9708289).

Burns, G.W. (2005). 101 Healing Stories for Kids and Teens Using Metaphors in Therapy. New Jersey: John Wiley\&Sons.

Cook, J.W., Taylor, L.A., Silverman, P. (2004). The Application of Therapeutic Storytelling Techniques With Preadolescent Children: A Clinical Description With Illustrative Case Study. Cognitive and Behavioral Practice, 2, 243-248.

Crenshaw D.A. (2008). Therapeutic engagement of children and adolescents: Play, symbol, drawing, and storytelling strategies. New York: Jason Aronson.

Faber, N., Faber, R. (2012) Piano Adventures. Michigan: Hal Leonard.

Henter, R., Chifor, G. (2015). Developing Preschool Children's Socio-Emotional Abilities through Therapeutic Stories. Journal Plus Education, 12, 195-200.

Liu, X. (2017). Exploring the Value of CulturallyAdaptedTherapeuticStoriesasa Tool for Intervention in Chinese Primary Schools. (Unpublished doctoral dissertation). The University of Sheffield, Sheffield, England.

Mitchell, E. (2016), Therapeutic Music Education: An Emerging Model Linking Philosophies and Experiences of Music Education with Music Therapy. Canadian Journal of Music Therapy, 22(1), 19-41.
Painter, L. T. (1997). Effects of therapeutic storytelling and behavioral parent training on the problem behaviors of children and on parental stress. (Master's Thesis). Available from ProQuest Dissertations \& Theses Global database. (UMI No. EP41177)

Rizzi, V., Pigeon, C., Rony, F., FortTalabard, A. (2020). Designing a creative storytelling workshop to build selfconfidence and trust among adolescents. Thinking Skills and Creativity, 38, 1-10. https://doi.org/10.1016/j. tsc.2020.100704.

Saldız, H., Berrak, K., Çavuşoğlu, H. (2020). Terapötik Hikaye Serisi. İstanbul:

Sihirli Kalem.

Schlindwein, H.E. (2009). Zoela's Stories Therapeutic Children's Stories. Lulu Press.

Sheppard, C.H. (1998). Brave Bart: AStory for Traumatized and Grieving Children. Michigan: The National Institute for Trauma and Loss in Children.

Sunderland, M. (2017). Using Story Telling as a Therapeutic Tool with Children. Abingdon: Routledge.

Thompson, J. (2011) John Thompson's Easiest Piano Course. Ohio: Willis Music. 
